\title{
What can we learn from amino acids about oceanic organic matter cycling and degradation?
}

\author{
Birgit Gaye $^{1}$, Niko Lahajnar ${ }^{1}$, Natalie Harms ${ }^{1}$, Sophie Anna Luise Paul ${ }^{2,3}$, Tim Rixen ${ }^{1,4}$, and Kay-Christian Emeis ${ }^{1}$ \\ ${ }^{1}$ Institute for Geology, Universität Hamburg, 20146 Hamburg, Germany \\ ${ }^{2}$ Department of Physics and Earth Sciences, Jacobs University Bremen, 28759 Bremen, Germany \\ ${ }^{3}$ GEOMAR, Helmholtz-Zentrum für Ozeanforschung, 24148 Kiel, Germany \\ ${ }^{4}$ Leibniz Centre for Tropical Marine Research (ZMT), 28359 Bremen, Germany
}

Correspondence: Birgit Gaye (birgit.gaye@uni-hamburg.de)

Received: 26 August 2021 - Discussion started: 31 August 2021

Revised: 5 January 2022 - Accepted: 8 January 2022 - Published: 10 February 2022

\begin{abstract}
Amino acids (AAs) mainly bound in proteins are major constituents of living biomass and non-living organic material in the oceanic particulate and dissolved organic matter pool. Uptake and cycling by heterotrophic organisms lead to characteristic changes in AA composition so that AAbased biogeochemical indicators are often used to elucidate processes of organic matter cycling and degradation. We analyzed particulate AA in a large sample set collected in various oceanic regions covering sinking and suspended particles in the water column, sediment samples, and dissolved AA from water column and pore water samples. The aim of this study was to test and improve the use of AA-derived biogeochemical indicators as proxies for organic matter sources and degradation and to better understand particle dynamics and interaction between the dissolved and particulate organic matter pools. A principal component analysis (PCA) of all data delineates diverging AA compositions of sinking and suspended particles with increasing water depth. A new sinking particle and sediment degradation indicator (SDI) allows a fine-tuned classification of sinking particles and sediments with respect to the intensity of degradation, which is associated with changes of stable isotopic ratios of nitrogen $\left(\delta^{15} \mathrm{~N}\right)$. This new indicator is furthermore sensitive to sedimentary redox conditions and can be used to detect past anoxic early diagenesis. A second indicator emerges from the AA spectra of suspended particulate matter (SPM) in the epipelagic and that of the meso- and bathypelagic ocean and is a residence time indicator (RTI). The characteristic changes in AA patterns from shallow to deep SPM are recapitulated in the AA spectra of the dissolved organic matter (DOM) pool, so that deep
\end{abstract}

SPM is more similar to DOM than to any of the other organic matter pools. This implies that there is equilibration between finely dispersed SPM and DOM in the deep sea, which may be driven by microbial activity combined with annealing and fragmentation of gels. As these processes strongly depend on physico-chemical conditions in the deep ocean, changes in quality and degradability of DOM may strongly affect the relatively large pool of suspended and dissolved AA in the ocean that amounts to $15 \mathrm{Pg}$ amino acid carbon (AAC) and $89 \pm 29$ Pg AAC, respectively.

\section{Introduction}

Amino acids (AAs) are ubiquitous in living organisms and comprise a major share of characterized organic matter in the particulate and dissolved pool in the ocean (Lee, 1988; Wakeham et al., 1984; Zhang et al., 2016; Davis et al., 2009; Lee et al., 2004). AAs contribute more than $80 \%$ of total organic carbon in fresh autochthonous plankton while allochthonous organic matter from continental runoff and atmospheric deposition has lower AA contents (Degens and Ittekkot, 1983, 1985). Most of the primary productivity occurs in the sunlit surface layer of the ocean, and most of the allochthonous material is also transported into surface waters. Thus, organic matter concentrations including their major biogenic constituents generally have a surface maximum and decrease with depth (Peters et al., 2018; Gaye et al., 2013b; Wakeham and Lee, 1993). The main mechanism behind this depthdependent distribution is that most of the organic matter is 
recycled in surface waters while only a small proportion of surface particles leave the surface waters by gravitational settling in the form of macroaggregates or fecal pellets. Particles containing organic matter, shells, frustules of organisms, and mineral matter sink at speeds of $200 \mathrm{~m} \mathrm{~d}^{-1}$ on average and constitute the export from the surface mixed layer or euphotic zone into the deep ocean, where part of it can ultimately reach the sediments (Alldredge and Silver, 1988; Alldredge, 1998; Pilskaln and Honjo, 1987; Fowler and Knauer, 1986; Karl et al., 1988; Rixen et al., 2019b). Sinking particles are caught by moored or floating sediment traps while suspended matter (SPM) is sampled by filtration or ultrafiltration of water from water samplers or by pump systems (Yamaguchi and McCarthy, 2018). SPM is too small to sink and therefore - like dissolved organic matter (DOM) - predominantly enters deep water by subduction of surface waters (Resplandy et al., 2019; Boyd et al., 2019) and is transported passively following the route of ocean water along the ocean conveyer belt (Silver et al., 1998; McCave, 1984). It has thus been surmised that the long residence time of SPM in the water column should result in a more degraded state compared with organic matter of sinking particles (McCave, 1984; Degens and Ittekkot, 1984). Studies of pigments, AAs, and fatty acids, however, do not find such a systematic difference between the two types of particles and even indicate that SPM can be less degraded than sinking particles (Abramson et al., 2011; Rontani et al., 2011; Wakeham and Canuel, 1988). In two studies of AA composition in the Benguela upwelling system and in the Arabian Sea, it was shown that the degradation pathways of SPM and sinking particles differ as their AA compositions diverge with depth (Gaye et al., 2013b; Nagel et al., 2009). These studies suggested that there is only little interaction between suspended and sinking particle pools below the euphotic zone. Due to its long residence time in the ocean, SPM appears to interact with DOM (Gaye et al., 2013b) and therefore carries different AA signatures related to genesis and history of organic matter cycling in its specific water mass (Nagel et al., 2016). Whereas information on the composition of sediment trap samples has been compiled in comprehensive studies (Honjo et al., 2008; Wilson et al., 2012; Rixen et al., 2019a, b), similar compilations of the profuse literature on suspended matter are still missing.

On the way to the deep sea the flux of sinking particles is reduced by disaggregation and organic matter degradation. Suess (1980) empirically derived the first power function for organic carbon decay based on sediment trap data. Subsequently, a large number of similar functions were calculated for various oceanic areas based on trap experiments (Rixen et al., 2002, 2019b; Armstrong et al., 2002; Martin et al., 1987). Early work on AAs had produced similar decay functions combining data from Atlantic and Pacific trap experiments (Lee and Cronin, 1982, 1984). As AAs decay faster than bulk organic carbon (Haake et al., 1993b, 1992, 1996; Lee et al., 2004; Wakeham and Lee, 1989; Whelan and
Emeis, 1992), they are often considered "labile" constituents of bulk organic matter. This is supposedly due to their preferential uptake as a nitrogen $(\mathrm{N})$ source for further synthesis of AA or as a source of essential AA for heterotrophs (Ittekkot and Arain, 1986; Ittekkot et al., 1986). This has been questioned, as a large proportion of the oceanic organic $\mathrm{N}$ pool is comprised of AAs that are not bioavailable (Aluwihare et al., 2005). In addition to the quantification of AA decay, degradation state of organic matter (proteins) can be assessed by characteristic changes in AA monomer composition, which, furthermore, has the potential to elucidate sources of organic matter and degradation processes (Ittekkot et al., 1984a, b; Dauwe and Middelburg, 1998; Dauwe et al., 1999; Jennerjahn and Ittekkot, 1997).

Ratios of individual amino acids such as the reactivity index (RI) (Jennerjahn and Ittekkot, 1997) or the degradation index (DI) normalizing AA data to the results of a principal component analysis (PCA) (Dauwe et al., 1999; Dauwe and Middelburg, 1998) have often been used to scale organic matter degradation (Niggemann et al., 2018; Unger et al., 2005; Ingalls et al., 2004, 2006; Pantoja et al., 2004; Möbius et al., 2010). These biogeochemical indicators of organic matter quality were essentially developed for marine sinking particles and sediments. Although based on marine sediments only (Dauwe et al., 1999), the DI was applied for example to SPM samples from the brackish environment (Unger et al., 2005) or even to trace dissolved AA degradation (Davis and Benner, 2005; Guo et al., 2018). Other work used individual and adapted indices to differentiate the states of degradation in SPM or DOM samples and samples from lakes, groundwater, and rivers (Abramson et al., 2011; Gaye et al., 2007; Goutx et al., 2007; Kaiser and Benner, 2009; Menzel et al., 2013; Peter et al. 2012; Sheridan et al., 2002).

Understanding and quantifying AA degradation is required to estimate the diagenetic imprint on $\delta^{15} \mathrm{~N}$ ratios of particulate matter. This is important as $\delta^{15} \mathrm{~N}$ ratios track major shifts between $\mathrm{N}$ pools and are commonly used to reconstruct the $\mathrm{N}$ cycle from sedimentary archives (Galbraith et al., 2013). Amino acid nitrogen (AAN) comprises $80 \%-$ $100 \%$ of $\mathrm{N}$ in fresh organic matter and is the precursor of most of the $\mathrm{N}$ buried in sediments and ultimately stored in the form of ammonium, adsorbed to clay minerals (Boyd, 2001; Waples and Sloan, 1980; Müller, 1977). Considerable AA degradation already occurs in the water column and progresses during organic matter burial in the sediments so that the impact of diagenetic processes on $\delta^{15} \mathrm{~N}$ has to be accounted for (Möbius et al., 2010, 2011; Niggemann et al., 2018; Carr et al., 2016). Ammonification leads to a diagenetic increase in $\delta^{15} \mathrm{~N}$ values by up to $6.5 \%$ in deep sea sediments while there is little effect during organic matter burial in shelf and slope sediments due to the higher sedimentation rates and sub- to anoxic diagenetic conditions (Tesdal et al., 2013; Robinson et al., 2012; Möbius, 2013; Gaye-Haake et al., 2005). Such $\delta^{15} \mathrm{~N}$ increases were shown to correlate with AA-derived degradation indicators so that the primary $\delta^{15} \mathrm{~N}$ 
signal from the water column can be reconstructed (GayeHaake et al., 2005; Gaye et al., 2009; Möbius et al., 2011).

DOM comprising the largest oceanic organic matter pool is defined by the pore size of the filters it passes through, which is 0.2-0.7 $\mu \mathrm{m}$ (Carlson and Hansell, 2015), and thus includes some picoplankton cells and all viruses (Aristegui et al., 2009). DOM in surface water is partly labile and can originate from the exudates and lysis of organisms, passive diffusion, or "overflow" out of phytoplankton and bacteria. Grazers can excrete or egest DOM; it can furthermore be leached from their fecal pellets or released by sloppy zooplankton feeding and is thus primarily released and also taken up in the surface ocean (Carlson and Hansell, 2015). Moreover, terrestrially derived DOM is transported into surface waters by rivers and via the atmosphere (Benner et al., 2005). Deep DOM has a different source than simply transport of surface DOM by intermediate and deep water formation and mixing, as deep DOM is refractory in nature and has been heterotrophically altered by cycling and degradation processes (Yamaguchi and McCarthy, 2018) discernible from their composition of dissolved AA (Kaiser and Benner, 2009; McCarthy et al., 2004). The possible source of deep DOM may be the release from sinking or suspended particles associated with microbial degradation on particles and in the ambiance of particles by processes such as solubilizing organic matter by ectohydrolase (Cho and Azam, 1988; Ciais et al., 2014; Aristegui et al., 2009). DOM can also be released from sediment pore water into overlying waters (Lahajnar et al., 2005). Ratios of $\delta^{15} \mathrm{~N}$ in ultrafiltered DOM (UDOM) showed no systematic change with depth and suggested a common microbial source or viral lysis (McCarthy et al., 2007).

In the following synoptic compilation of AA data, we will examine the differences in AA spectra of a large data set that combines dissolved and particulate AAs from plankton, suspended and sinking material, and sediments from different oceanic regions, as well as from riverine to brackish-marine conditions. Focusing on processes in the water column, the data serve to (i) test existing AA-based biogeochemical indicators of organic matter sources and degradation, (ii) better understand transformation and degradation processes of organic matter in aquatic environments reflected by AA composition in sinking and suspended particles and total dissolved AAs (TDAAs), (iii) investigate the impact of such processes on the $\delta^{15} \mathrm{~N}$ values, and (iv) identify open questions which may be pursued with the help of AA analyses in the future.

\section{Materials and methods}

\subsection{Sampling}

A total of 1425 samples were taken for AA analyses in different oceanic areas and water depths between 1993 and
2017 and include 218 sediment trap samples, 489 sediment samples, 608 SPM samples, and 110 water and pore water samples (Fig. 1a-d). Five additional plankton samples were taken in the Arabian Sea and from the Namibian upwelling area by plankton tows between $0-100 \mathrm{~m}$ and between 100 $700 \mathrm{~m}$ water depths. In the Kara Sea - a shallow shelf sea strongly impacted by water and suspended matter discharge from the rives $\mathrm{Ob}$ and Yenisey - sediment traps, surface sediments, and suspended matter were sampled (Gaye et al., 2007; Gaye-Haake et al., 2003; Nagel et al., 2009; Unger et al., 2005). In the deep Mediterranean Sea sediment traps and surface sediments were sampled (Möbius et al., 2010). SPM from the Mediterranean Sea was only analyzed for $\delta^{15} \mathrm{~N}$ values (Emeis et al., 2010). Sediment trap as well as surface sediment, SPM, and water samples were taken along crossshelf transects off Namibia (Nagel et al., 2013, 2016). Sediment trap samples and short sediment cores were taken at two stations in the northeastern Atlantic (Lahajnar et al., 2005; Turnewitsch et al., 2015, 2017). In the Arabian Sea sediment trap, SPM and surface sediment samples were taken in the deep ocean and on the continental slope, including a core within the oxygen minimum zone at water depths of $775 \mathrm{~m}$ (Gaye et al., 2013a, b; Rixen et al., 2014; Gaye-Haake et al., 2005; Suthhof et al., 2000, 2001). In the Indian Ocean Subtropical Gyre sediment trap, SPM and water samples were taken (Harms et al., 2019, 2021), and samples from the equatorial North Pacific and eastern South Pacific are comprised of bottom water, pore water, and sediment core samples (Paul et al., 2018).

Sea water was filtered through glass fiber filters (Whatman $\mathrm{GF} / \mathrm{F}$ ) with a nominal pore size of $0.7 \mu \mathrm{m}$, and filters were dried at $40^{\circ} \mathrm{C}$ in order to obtain SPM samples. At some stations water samples were taken by deep freezing an aliquot of the filtrate for TDAA analyses. In addition, 18 water samples taken off Namibia were separated into two size classes by ultrafiltration (Brockmeyer and Spitzy, 2013). The size classes $50 \mathrm{kDa}-0.7 \mu \mathrm{m}$ and $1 \mathrm{kDa}-0.7 \mu \mathrm{m}$ were used for TDAA analyses. Sediment trap samples were wet sieved on board and comprise the $<1 \mathrm{~mm}$ fraction, filtered with polycarbonate Nuclepore filters of $0.45 \mu \mathrm{m}$ pore size and dried at $40^{\circ} \mathrm{C}$. Sediment samples from multicores, box grabs, box cores, or gravity cores were taken by spatula or syringes from coldstored cores and were freeze-dried before analyses. Surface samples represent either the upper $0.5 \mathrm{~cm}$ or $1 \mathrm{~cm}$ of a sediment core. Pore water samples were taken by rhizons with a mean pore size of $0.15 \mu \mathrm{m}$ and stored frozen before analyses (see methods in Paul et al., 2018).

\subsection{Analytical methods}

Total carbon and $\mathrm{N}$ were measured with a Carlo Erba nitrogen analyzer 1500 (Milan, Italy) or a EURO EA3000 elemental analyzer. Particulate organic carbon (POC) was measured after treatment of weighed samples with $1 \mathrm{~N} \mathrm{HCl}$ to remove carbonate. The precision of this method is $0.05 \%$ 

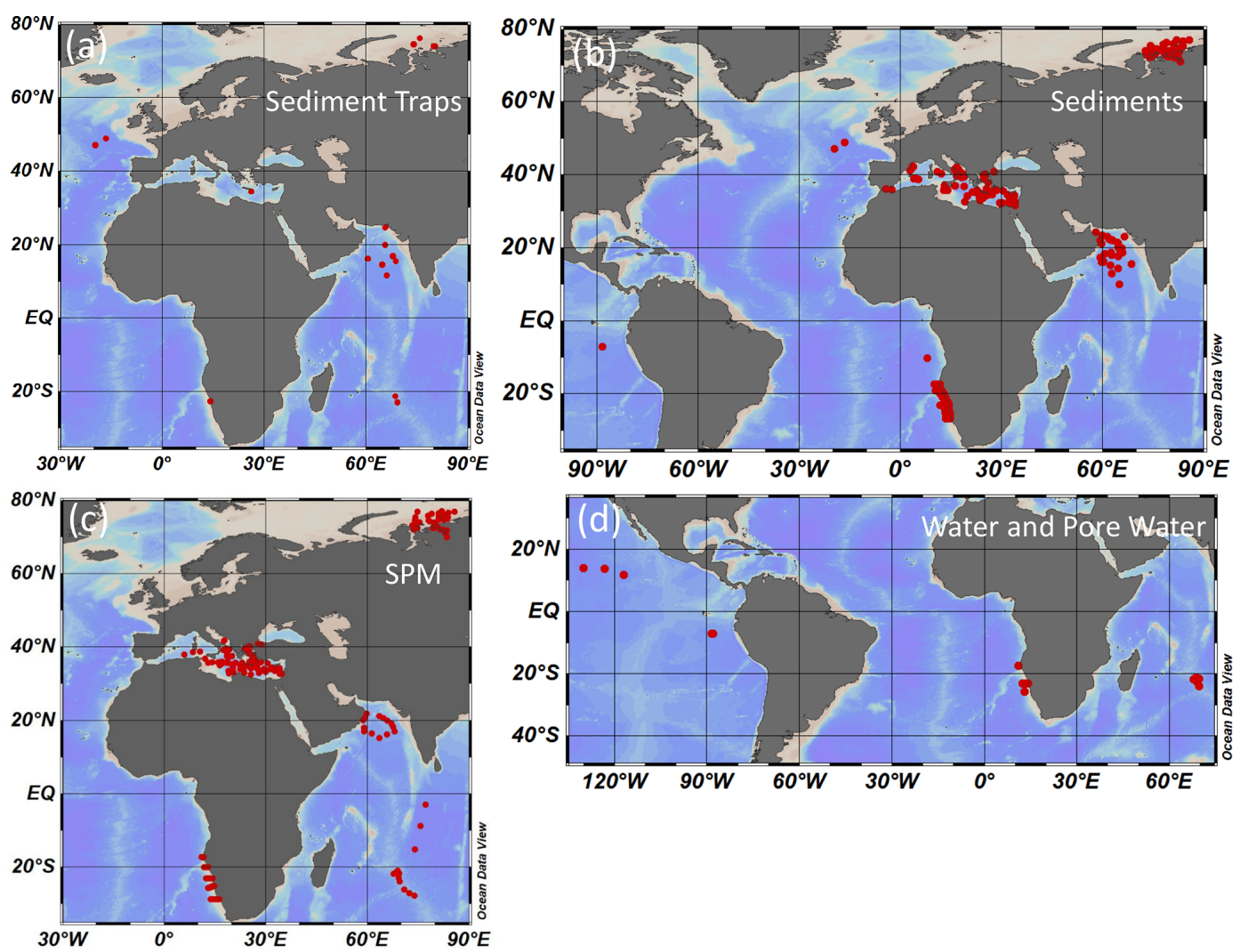

Figure 1. Stations of sediment trap deployments (a), sediment (b), SPM (c), and water and pore water sampling (d).

for carbon and $0.005 \%$ for N. Carbonate carbon was calculated by subtracting organic carbon from total carbon. Ratios of ${ }^{15} \mathrm{~N} /{ }^{14} \mathrm{~N}$ of particulate $\mathrm{N}$ were determined using a Thermo Finnigan MAT 252 isotope ratio mass spectrometer connected with a ConFlo III interface after high-temperature flash combustion in a Thermo Finnigan Flash EA 1112 at $1050^{\circ} \mathrm{C}$. Part of the samples were measured with an Elementar IsoPrime 100 isotope ratio mass spectrometer after hightemperature combustion in an Elementar CHNOS Vario isotope elemental analyzer at $950^{\circ} \mathrm{C}$. Pure tank $\mathrm{N}_{2}$ calibrated against the reference standards IAEA-N1 (ammonium sulfate, $\delta^{15} \mathrm{~N}=+0.4 \%$ o versus air $\mathrm{N}_{2}$ ) and IAEAN2 (ammonium sulfate, $\delta^{15} \mathrm{~N}=+20.3 \%$ ) of the International Atomic Energy Agency was used as a working standard. Duplicate measurements of samples differ by less than $0.15 \%$. The laboratory's long-term standard deviation for the IAEA-N1 standard is $0.09 \%$. $\mathrm{N}$-isotope ratios are reported in per mille using the delta notation and the ${ }^{15} \mathrm{~N} /{ }^{14} \mathrm{~N}$ of air $\mathrm{N}_{2}$ as the reference standard:

$$
\begin{aligned}
\delta^{15} \mathrm{~N}_{\text {sample }} & =\left(\left({ }^{15} \mathrm{~N} /{ }^{14} \mathrm{~N}\right)_{\text {sample }}\right. \\
& \left./\left({ }^{15} \mathrm{~N} /{ }^{14} \mathrm{~N}\right)_{\text {reference standard }}-1\right) \times 1000 .
\end{aligned}
$$

Dissolved organic carbon (DOC) concentrations [ $\mathrm{mg} \mathrm{L}^{-1}$ ] were determined of water and pore water samples via a hightemperature combustion method (POC- $\mathrm{V}_{\mathrm{CSH}}$ analyzer, Shimadzu). Inorganic carbon was removed by $2 \mathrm{M} \mathrm{HCl}$ prior to injection into the combustion tube where organic carbon is oxidized to $\mathrm{CO}_{2}$ at $680{ }^{\circ} \mathrm{C}$ with a platinum catalyst. A five-point calibration from 0.5 to $5 \mathrm{mg} \mathrm{DOC} \mathrm{L}^{-1}$ was used. The error of measurement is less than $2 \%$ (Brockmeyer and Spitzy, 2013).

TDAA, particulate AA, and hexosamines (HA) were analyzed with a Biochrom 30 amino acid analyzer. Acid hydrolysis with $6 \mathrm{~N} \mathrm{HCl}$ for $22 \mathrm{~h}$ at $110^{\circ} \mathrm{C}$ under a pure argon atmosphere was carried out on ca. $3 \mathrm{~mL}$ of filtrate of water and pore water samples, on 1-2 mg of suspended matter collected on Whatman GF/F filters, on 1-2 mg of sediment trap samples, or on $1-50 \mathrm{mg}$ of freeze-dried surface sediments. A particle-free aliquot was evaporated three times to dryness in order to remove the unreacted $\mathrm{HCl}$; the residue was taken up in an acidic buffer ( $\mathrm{pH} 2.2)$. After injection and subsequent separation with a cation exchange resin, the individual AA monomers were post-column derivatized with $o$ phthaldialdehyde in the presence of 2-mercaptoethanol and detected with a Merck Hitachi L-2480 fluorescence detector. Duplicate analysis of a standard solution according to this method results in a relative error of $0.1 \%-1.3 \%$ for 
the concentrations of individual AA monomers and $0.2 \%-$ $3.0 \%$ for individual AA monomers of water or particulate matter samples. Due to acid hydrolysis, aspartic acid (ASP) and asparagine (Asn) are both measured as Asp, and glutamic acid (Glu) and glutamine (Gln) are both measured as Glu. The other AAs measured are threonine (Thr), serine (Ser), glycine (Gly), alanine (Ala), valine (Val), methionine (Met), isoleucine (Ile), leucine (Leu), tyrosine (Tyr), phenylalanine (Phe), $\beta$-Alanine ( $\beta$-Ala), $\gamma$-aminobutyric acid $(\gamma$ Aba), histidine (His), ornithine (Orn), lysine (Lys), and arginine (Arg). The HAs measured together with AAs are glucosamine (Gluam) and galactosamine (Galam), and their total contents were corrected with a factor of 1.4 for loss during hydrolysis (Müller et al., 1986).

\subsection{Amino-acid-derived biogeochemical indicators of organic matter origin and degradation}

Amino acid concentrations and the contribution of AA carbon (AAC) and AA nitrogen (AAN) as percentages of total organic carbon $(\mathrm{AAC} / \mathrm{C})$ or total $\mathrm{N}(\mathrm{AAN} / \mathrm{N})$ are used to determine the degradation state of organic matter in the marine realm as both decrease with increasing organic matter degradation (Wakeham and Lee, 1993; Cowie and Hedges, 1994). AAN / N $>50 \%$ are characteristic of fresh organic matter in the freshwater and marine realm (Menzel et al., 2015; Haake et al., 1992, 1993b). AAs contribute $>60 \%$ to total organic carbon (AAC/C) in fresh plankton and suspended matter in surface waters, whereas $\mathrm{AAC} / \mathrm{C}$ drop to values $<20 \%$ in sinking particles and suspended matter from subsurface water (Wakeham and Lee, 1993). AAC / C values are often below $10 \%$ in freshwater environments and indicate the enhanced input of land plants enriched in carbohydrates and lignin rather than enhanced organic matter degradation (Menzel et al., 2015).

Asn, Gln, and Glu are the primary products of $\mathrm{N}$ assimilation, and all other AAs are synthesized from them (LoickWilde et al., 2018; Riccardi et al., 1989; Hildebrandt et al., 2015). Asp and Glu are enriched in bacteria, vascular plant tissue, phytoplankton, zooplankton, and fungi, and their high relative contents of Asp and Glu therefore indicate fresh organic matter (Cowie and Hedges, 1992). The ratios of Asp / $\beta$-Ala and Glu / $\gamma$-Aba are high in fresh organic matter and drop with organic matter degradation as $\beta$-Ala and $\gamma$-Aba are degradation products of Asp and Glu, respectively (Lee and Cronin, 1984). $\beta$-Ala and $\gamma$-Aba also become relatively enriched during organic matter degradation as these non-protein AAs are not taken up by heterotrophic organisms (Ittekkot et al., 1984b).

The relative accumulation of the non-protein AAs is also expressed by the RI, which is the ratio of the very labile aromatic AAs Tyr and Phe and the non-protein AAs $\beta$-Ala and $\gamma$-Aba. The RI is, generally, between 0 (very degraded) and 15 (very fresh) (Jennerjahn and Ittekkot, 1997). It is applicable not only in studies of sinking and suspended mat- ter in marine and brackish environments (Unger et al., 2005; Gaye et al., 2007) but also as a proxy for degradation state in the sediment column (Möbius et al., 2011). The enrichment of Asp and Glu in sediments is related to their enrichment in carbonate shells (Ittekkot et al., 1984a) and to adsorption of primarily acidic AAs onto carbonate minerals (King and Hare, 1972), whereas basic AAs primarily adsorb onto silicate minerals (Hedges and Hare, 1987; Keil et al., 1994; King, 1975).

The DI, the integral of 14 protein AAs, assesses the diagenetic alteration of a sample by comparing it to a set of 28 sediment samples of different degradation states and environments. Molar percentages of individual AAs are standardized by the mean and standard deviations of the 28-sample data set. The DI then integrates the result of these standardized values weighed by the factor coefficients for the first axis of the PCA of Dauwe et al. (1999) according to the formula

$\mathrm{DI}=\sum_{i}\left(\frac{\operatorname{var}_{i}-\mathrm{AVG}_{\mathrm{var}}}{\mathrm{SD} \cdot \mathrm{var}_{i}}\right) \times{\text { fac. } \operatorname{coef}_{i}}$

where $\operatorname{var}_{i}$ is the original mole percentage of each $\mathrm{AA}_{i}$; AVG.var $i$ and SD.var $i$ are the mean and standard deviations, respectively; and fac. $\operatorname{coef}_{i}$ is the factor coefficient of the first axis of the PCA of Dauwe et al. (1999). The DI thus represents the cumulative deviation of $\mathrm{AA}$ with respect to an assumed average molar composition. The DI ranges approximately from -2 to +3 , where negative values indicate more and positive values less degradation than the average.

A specifically designed index for dissolved substances (DOM-DI) calculated in the same way as the DI was based on a PCA of a set of marine DOM samples and resulted in DOM-DI values from 5 in surface waters to -3 in deep waters (Kaiser and Benner, 2009). The values to calculate the marine DOM-DI (averages, standard deviations, and factor coefficients of F1) can be found in Peters et al. (2012).

An indicator of oxic vs. anoxic organic matter degradation in the water column and in sediments was proposed by Menzel et al. (2015) for lake samples. Based on work by Cowie et al. (1995) on marine sediments, the ox / anox indicator is the quotient of AAs preserved under oxic diagenetic conditions to those preserved in anoxic water or sediments and is thus higher in oxic than in anoxic sediments:

$\mathrm{ox} / \mathrm{anox}=\frac{\mathrm{Asp}+\mathrm{Glu}+\beta-\mathrm{Ala}+\gamma-\mathrm{Aba}+\mathrm{Lys}}{\text { Ser }+ \text { Met }+ \text { Ile }+ \text { Leu }+ \text { Tyr }+ \text { Phe }}$.

ox / anox ratios $<1.0$ indicate anoxic and ratios $>1.5$ oxic diagenesis (Menzel et al., 2015).

The stability of AA vs. HA has been discussed since the early research on AA and HA in natural material. Fresh plankton was observed to have AA / HA ratios of 13-25 (Degens and Mopper, 1975), which is a mixed signal of phytoplankton with an AA / HA ratio of $>80$ and zooplankton with a ratio of $\sim 9$ due to chitinaceous skeletons of many zooplankters (Mayzaud and Martin, 1975). Low AA/HA 
ratios are also observed in cell walls of fungi and bacteria. As the building blocks of chitin, HAs were assumed to be more resistant to degradation than bulk AAs (Müller et al., 1986). This is, however, challenged by studies of enzyme activities, which were observed to respond to substrate availability so that the activity of chitobiase and chitinase is as high as that of glucosidase (Boetius et al., 2000a, b; Boetius and Lochte, 1994; Smith et al., 1992), suggesting intense degradation also of chitin. Gluam is the main constituent of chitin while Galam is relatively enriched in bacterial cell walls (Walla et al., 1984; Kandler, 1979). The Gluam / Galam ratio has, therefore, been used to distinguish bacterial material from zooplankton-rich material (Haake et al., 1993b; Benner and Kaiser, 2003; Niggemann and Schubert, 2006). Gluam / Galam ratios $>4$ were found in sinking particles (Haake et al., 1993b; Haake et al., 1992; Lahajnar et al., 2007), ratios of $<3$ usually indicate relatively high contribution of microbial OM, and values between 1 and 2 are characteristic of sediments and indicate an enrichment of microbial biomass (Benner and Kaiser, 2003).

\subsection{Statistical analyses}

To investigate the differences of AA composition and to recognize the interaction and pathways of degradation between the different pools, we carried out a PCA of AA monomer contributions in Mol\%. Met was excluded as it is below detection limit in many samples. The PCA was carried out using the program SPSS Statistics 22. PCAs have often been used to analyze large databases (Xue et al., 2011) in order to trace organic matter degradation, group and categorize samples, and develop indices such as the DI of Dauwe et al. (1999) using summary statistics (see Eq. 2). A PCA is an orthogonal transformation of a set of variables into a new set of uncorrelated variables called principal components. New axes are chosen in order to explain as much as possible of the variance within the data set on a few main axes of the highest correlation. The first component explains most of the variance within the data set, consecutively followed by the remaining components in the order of their decreasing capacity to explain the variance within the data set. The selection of the most relevant components can be done by selecting those with eigenvalues (the variances of the principal components) $>1$. Alternatively, the kink method can be applied selecting those components from a plot of eigenvalues (scree plot), which describe a steep slope of declining variance followed by a "kink", after which the principal components add only small amounts to the variance. The factor loadings of the variables (in this case the individual amino acids) are their projections on the new axis. The factor score of each data set from a sampling location is obtained by multiplying the standardized data with the factor loadings (also called factor coefficients). A high (low) factor score shows that a sample has high (low) concentrations of the variables with high factor loadings. A plot of factor loadings of the variables compared with a plot of the factor scores of samples helps to visualize the relation of the samples to the variables and thus to identify the processes behind the results of the PCA.

\section{Results}

\subsection{Organic carbon, nitrogen, and amino acid content}

The POC $(\mathrm{N})$ content is $35.9 \%(5.9 \%)$ in plankton and $1.65 \%-46.4 \%(0.21 \%-10.14 \%)$ in sediment trap samples. In sediments, POC $(\mathrm{N})$ contents drop to $0.10 \%-13.5 \%$ $(0.02 \%-1.72 \%)$. SPM has POC $(\mathrm{N})$ contents of $0.94 \%-$ $45.4 \%(0.09 \%-12.08 \%)$. DOC concentration in water samples is between $0.5-1.1 \mathrm{mg} \mathrm{L}^{-1}$, and DOC in pore water samples is between $3.9-29 \mathrm{mg} \mathrm{L}^{-1}$.

AA concentrations are grouped into SPM and trap samples taken at water depths $<200 \mathrm{~m}$ (shallow) and $>200 \mathrm{~m}$ (deep) (Fig. 2, Table 1). AA concentrations are highest in SPM samples and shallow sediment traps $(<200 \mathrm{~m}$ water depth) with values between $40-4307 \mu \mathrm{mol} \mathrm{g}^{-1}$ (Fig. 2) and averages of $662-908 \mu \mathrm{mol} \mathrm{g}^{-1}$ (Table 1). AA concentrations are lower in traps from water depth $>200 \mathrm{~m}$ with an average of $164 \mu \mathrm{molg}^{-1}$. Sediments have the lowest AA concentrations of all particulate matter samples with an average of $50 \mu \mathrm{molg}^{-1}$ (Table 1). TDAA concentrations are between $0.6-44 \mu \mathrm{mol} \mathrm{L}{ }^{-1}$, and AA concentrations are lower in water than in pore water samples with averages of 3.2 and $8.8 \mu \mathrm{mol} \mathrm{L}^{-1}$, respectively. TDAA concentrations of water samples decrease from the epipelagic $\left(2.5 \pm 2.9 \mu \mathrm{mol} \mathrm{L}^{-1}\right)$ to the meso- and bathypelagic ocean $\left(1.2 \pm 0.5 \mu \mathrm{mol} \mathrm{L}{ }^{-1}\right)$ whereas bottom waters have enhanced TDAA concentrations even higher than those in surface waters $\left(6.0 \pm 3.4 \mu \mathrm{mol} \mathrm{L}^{-1}\right)$.

The AAC / C is between $5.4 \%-66 \%$ in SPM and trap samples, and the AAN / N (not shown) is between 3.7\%$100 \%$. The overall pattern found for AAC / C (Fig. 2b) is similar to the pattern of AA concentrations (Fig. 2a), but there is more overlap of AAC/C between the different groups. Sediments have AAC / C between $2.7 \%-50 \%$ and AAN / $\mathrm{N}$ between $3 \%-78 \%$ (not shown). The contribution of AAC to DOC (AAC / C) in water samples is between $4 \%-$ $40 \%$ and in pore water samples between $0.5 \%-9 \%$.

AA concentrations of sinking and suspended particles decrease with water depth, and the most significant decrease occurs in the upper ocean (Fig. 3a). The decay constant of AA of sinking particles is twice as high as the decay constant of AA of SPM (Fig. 3a, b). Kara Sea samples were excluded from these calculations as their AA concentrations are low due to the strong dilution by material from rivers and resuspended sediments in this near-shore environment (see Sect. 4.2). It is also notable that AAC / C and AAN / N (not shown) significantly decrease between shallow and deep traps and from deep traps to sediments while AAC / C of 

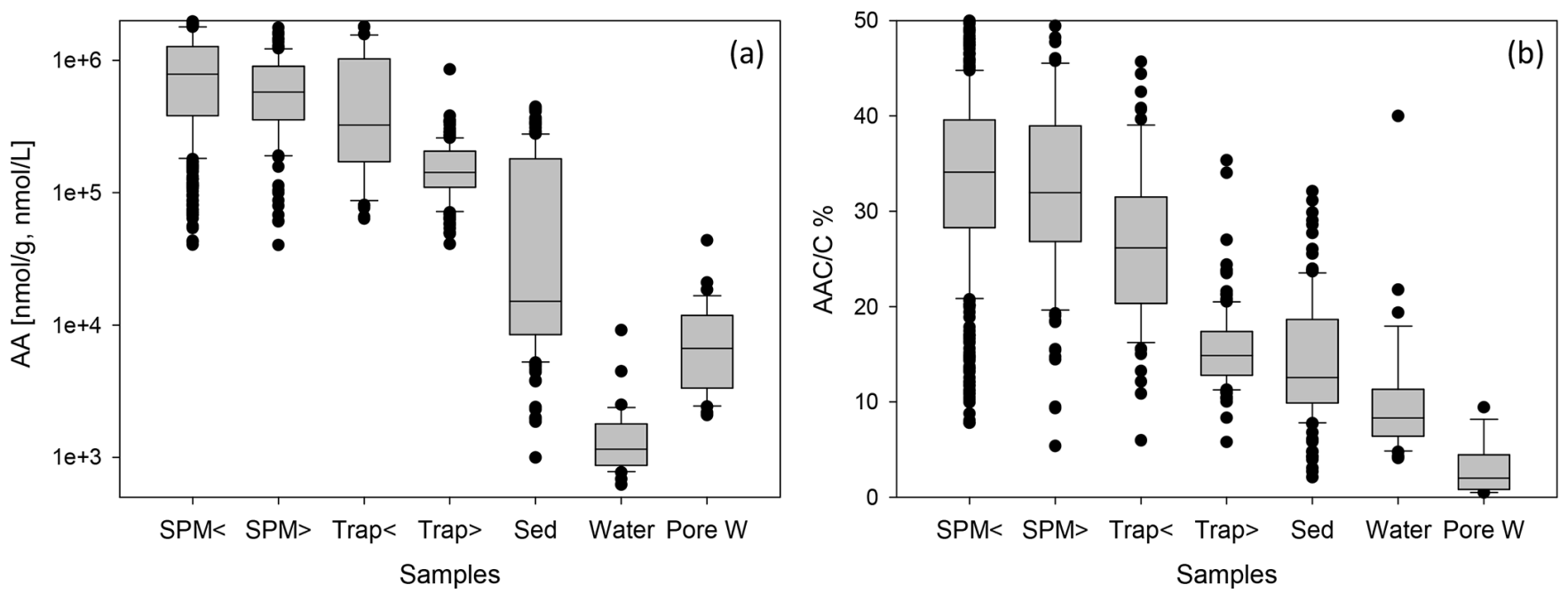

Figure 2. Box-and-whisker plots of AA concentrations in $\mathrm{nmol} \mathrm{g}^{-1}$ or $\mathrm{nmol} \mathrm{L}{ }^{-1}$ (a) and of AAC / C (b) in SPM from water depths $<200$ $(\mathrm{SPM}<)$ and $>200 \mathrm{~m}(\mathrm{SPM}>)$, in sediment traps at water depth $<200($ Trap $<)$ and $>200 \mathrm{~m}($ Trap $>)$, in sediments (Sed), in water samples (Water), and in pore water samples (Pore W). Boxes comprise the upper and lower quartiles, and lines indicate the median. Whiskers delineate the 10th and 90th percentiles. Outliers are marked by dots. Some outliers above the 90th percentile are cut off in the figure for better perceptibility of trends.
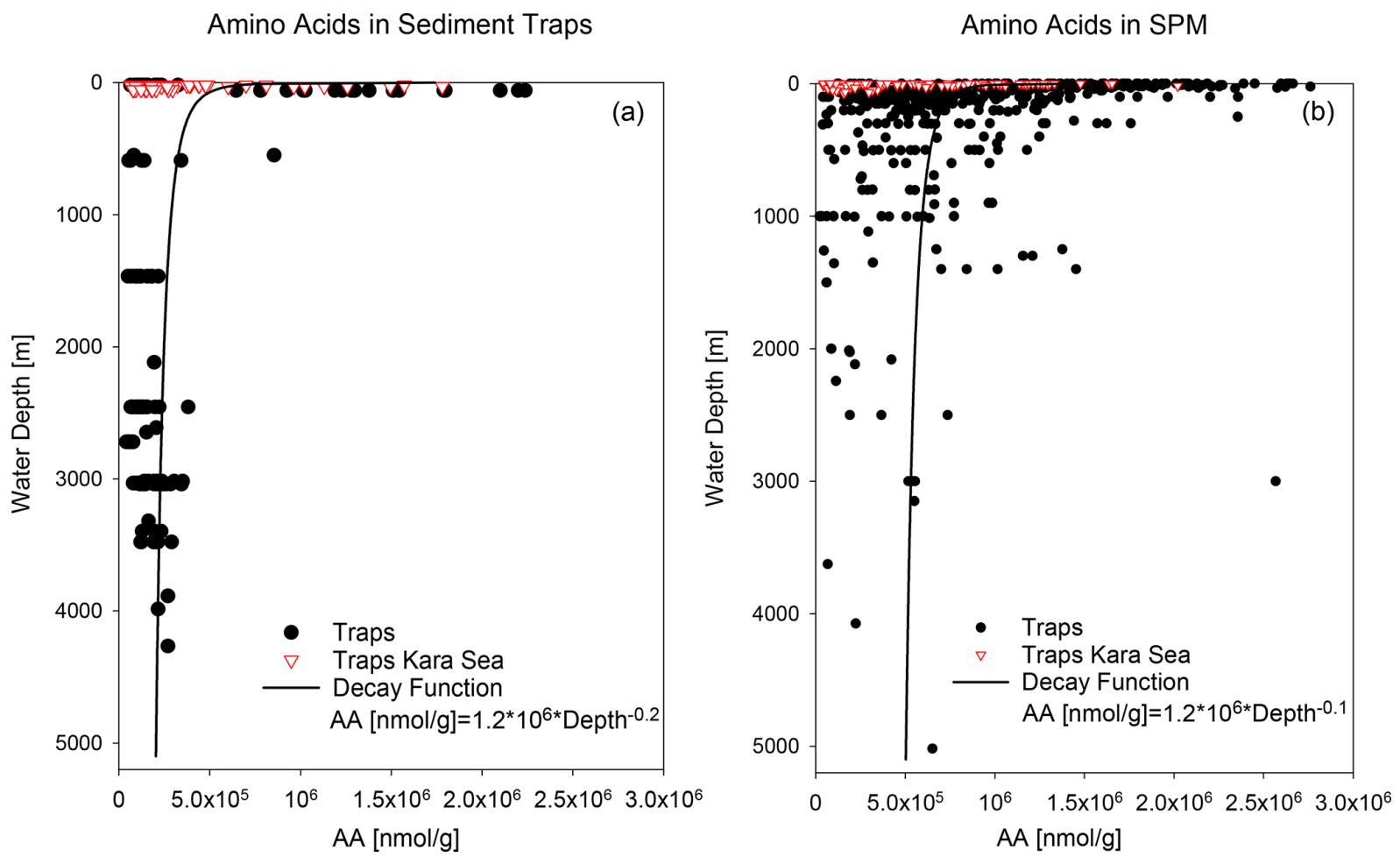

Figure 3. AA concentrations in $n m o l g^{-1}$ in sediment traps (a) and SPM (b). Red triangles mark samples from the Kara Sea, and black dots are samples from the other trap and SPM locations shown in Fig. 1. The decay functions are calculated from samples excluding Kara Sea samples. 
SPM show little decrease between shallow and deep samples (Fig. 2b).

\subsection{Amino acid composition}

While the AA concentrations of sinking particles from traps show a distinct decrease with water depths, the changes in AA composition are lesser so that we averaged all AA spectra irrespective of water depths and area of study to compare them with plankton and sediment samples (Fig. 4a). Dominant AAs in plankton samples are Glu, Gly, Ala, and Asp. Sinking particles and sediments are also dominated by these AAs but in the order of Gly, Asp, Glu, and Ala (Fig. 4a). Mol \% Asp, Gly, $\beta$-Ala, $\gamma$-Aba, and Orn increase from plankton via sinking particles to sediments while Mol \% of Glu, Ala, Val, Met, Ile, Leu, Tyr, and Phe decrease (Fig. 4a). These trends are further continued with depths in sediment cores (not shown).

AA composition of SPM shows a clear trend with water depth with enrichments of Mol \% Ser, Glu, Gly, Orn, and His and decreases of almost all other AAs from shallow waters $(<200 \mathrm{~m})$ to deep waters $(>200 \mathrm{~m})$, and decreases are most pronounced for Asp, Thr, and Lys (Fig. 4b). These trends are partly resumed by TDAA in water samples with a further enrichment of Mol\% Ser, Orn, and His, while Mol\% Glu and Gly slightly decrease in water samples compared with deep SPM (Fig. 4b). AA spectra of pore waters (not shown) are very similar to water samples.

Biogeochemical indicators reveal the subtle depthdependent trends in sediment traps, and therefore the biogeochemical indicators were averaged separately for shallow and deep sediment trap and SPM samples (Fig. 5, Table 1). The AA / HA ratios in SPM and water samples - with averages between 80.2 and 204.6 - are higher than in traps and sediments (Fig. 5a; Table 1). The AA / HA ratios decrease from shallow via deep traps to sediments with averages of 25.4, 14.9 and 9.1, respectively. The Gluam / Galam is highest in SPM samples and traps and lower in sediments, water, and pore water (Fig. 5a, b; Table 1). The RI (Fig. 5c; Table 1) shows the same pattern as the ratios of Asp / $\beta$-Ala and Glu / $\gamma$-Aba (Table 1), with no clear trend between shallow and deep SPM samples and decreases from shallow to deep traps and further to the sediments. Water samples have similar values as sediment samples with an average RI of 1.8 and 1.6, respectively, and pore waters have an even lower average RI of 0.9. Similar to the RI, the DI is within the same range in shallow and deep SPM samples, and the mean values are very close (Fig. 5d; Table 1) while the DI decreases from shallow sediment traps via deep traps to sediments. In contrast to the RI where water samples have the lowest values, the highest DI values are found in water and pore water samples. The DOM-DI averages of $2.0 \pm 0.6$ and $2.1 \pm 0.7$ in water and, respectively, pore water samples are in fact very close to the DI averages (Table 1).
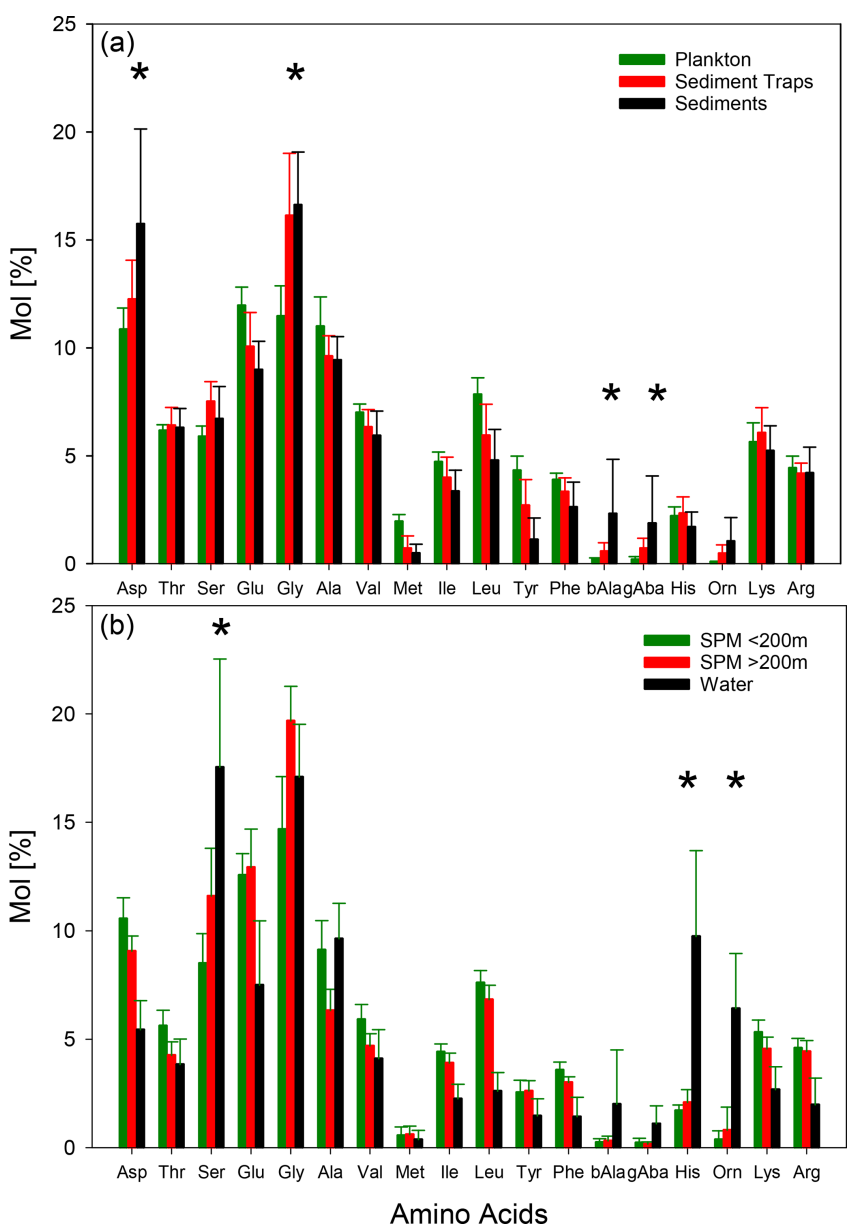

Figure 4. Average concentrations of individual AA (Mol\%) and $1 \sigma$ standard deviation (vertical bars) in plankton (green), sediment trap (red), and sediment (black) samples (a) and in SPM from water depths $<200$ (green), $>200 \mathrm{~m}$ (red), and TDAA in water samples (black) (b). Asterisks mark the AAs with increasing Mol\% from plankton via sediment trap samples to sediments (a) and from shallow SPM via deep SPM to TDAA of water samples.

In summary, common biogeochemical indicators of organic matter degradation (RI, Asp / $\beta$-Ala, Glu $/ \gamma$-Aba) and bacterial OM accumulation (AA / HA, Gluam / Galam) drop and thus imply increasing degradation between shallow and deep sediment traps and between deep traps and sediments, while these indicators reveal little or no degradation with depth in SPM as the patterns of relative enrichment vs. decreases found in SPM and partly also in TDAA of water and pore water samples differ from the degradation pathway depicted by common biogeochemical indicators (Figs. 4, 5; Table 1). The enhanced DI values furthermore imply that water and SPM samples are less degraded than deep trap and sediment samples and that TDAA in water and pore water samples are least degraded. 

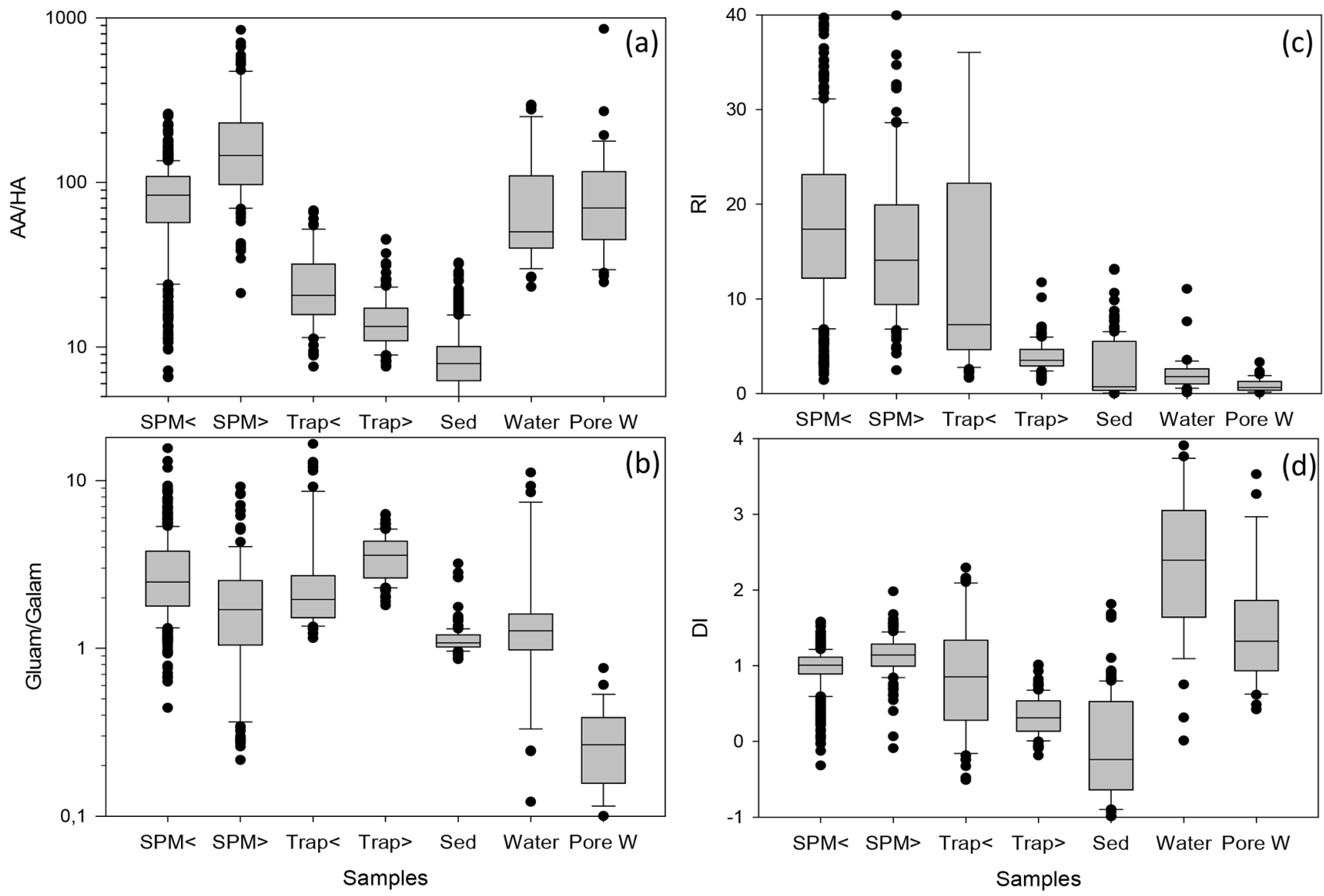

Figure 5. Box-and-whisker plot of AA / HA ratios (a) and Gluam / Galam ratios (b), RI (c), and DI (d) in SPM from water depths $<200$ $(\mathrm{SPM}<)$ and $>200 \mathrm{~m}(\mathrm{SPM}>)$, in sediment traps at water depth $<200$ (Trap $<)$ and $>200 \mathrm{~m}$ (Trap $>$ ), in sediments $($ Sed), in water samples (Water), and in pore water samples (Pore W). Outliers are marked by dots; some outliers above the 90th percentile are cut off for better perceptibility of trends. Note logarithmic scales of AA / HA (a) and Gluam / Galam (b).

\section{Discussion}

\subsection{Changes during organic matter degradation}

Our summary of AAs data from various locations in the world ocean corroborates earlier findings that degradation of organic matter by zooplankton and microbes imparts characteristic changes to AA spectra so that the differences in AA composition are much larger between types of organic matter and from different water and sediment depths than between different oceanic areas (Lee, 1988). The AA spectra track the successive degradation of organic matter during sedimentation from the plankton source via sinking particles, their incorporation into sediments, and their further degradation after burial. The most characteristic changes along this sedimentation pathway are the relative enrichments (in $\mathrm{Mol} \%$ ) of Gly, Asp, and the non-protein AA $\beta$-Ala, $\gamma$-Aba, and Orn and the relative decrease in AA produced by fresh plankton such as Glu, Ala, Val, Met, Ile, Leu, Tyr, and Phe (Fig. 4a). These changes are depicted by the common biogeochemical indicators: the ratios of proteinaceous AA vs. non-protein AA (RI and Glu / $\gamma$-Aba) decrease along this pathway. Asp / $\beta$-Ala ratios also decrease because $\beta$-Ala becomes relatively more enriched than Asp. The DI, originally derived from sediment samples of different degradation states (Dauwe et al., 1999; Dauwe and Middelburg, 1998), decreases from positive values in fresh plankton and most sinking particles to negative values in sediments as it integrates the products of Asp and Gly multiplied with negative factors and the products of Glu, Met, Ile, Leu, Tyr, and Phe multiplied with positive factors (Dauwe et al., 1999).

In contrast, the AAs in SPM evolve along a different path than the sedimentation pathway (Gaye et al., 2013b). The increases in Mol\% Ser, His, and Orn and the decreases in Mol \% Asp from shallow $(<200 \mathrm{~m})$ to deep SPM $(>200 \mathrm{~m})$ and even further in TCAA of sea water and pore water are either not depicted or even contrary to the trends depicted by the common biogeochemical indicators (Fig. 4b). The striking difference in AA distribution of SPM (Fig. 4) on the one hand and sinking particles and sediments on the other hand as well as the different depth-dependent trends (Figs. 4, 5) suggests that there is little exchange between the two types of 


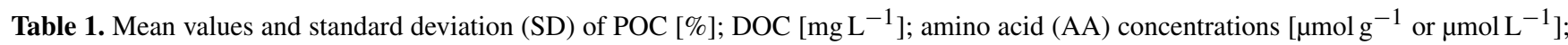
AAC / C\%; AAN / N\%; ratios of Asp / $\beta$-Ala, Glu / $\gamma$-Aba, AA / HA, and Gluam / Galam; RI; DI; SDI*; RTI*; and ox / anox ratio summarized in traps at $<200$ and $>200 \mathrm{~m}$ water depth, sediments, SPM $<200$ and $>200 \mathrm{~m}$ water depth, water samples, and pore water samples.

\begin{tabular}{|c|c|c|c|c|c|c|c|c|}
\hline & & Trap $<200 \mathrm{~m}$ & Trap $>200 \mathrm{~m}$ & Sediment & $\mathrm{SPM}<200 \mathrm{~m}$ & $\mathrm{SPM}>200 \mathrm{~m}$ & Water & Pore water \\
\hline \multirow[t]{2}{*}{ POC; DOC [\%; $\left.\mathrm{mg} \mathrm{L}^{-1}\right]$} & Mean & 13.6 & 5.3 & 1.8 & 14.9 & 10.6 & 0.8 & 13.0 \\
\hline & SD & \pm 11.4 & \pm 1.9 & \pm 2.2 & \pm 8.3 & \pm 4.8 & \pm 0.2 & \pm 8.3 \\
\hline \multirow[t]{2}{*}{$\mathrm{AA}\left[\mathrm{mmolg}^{-1} ; \mathrm{mmol} \mathrm{L}^{-1}\right]$} & Mean & 631.3 & 164.1 & 49.8 & 907.7 & 661.9 & 3.2 & 8.8 \\
\hline & SD & \pm 602.0 & \pm 93.8 & \pm 82.3 & \pm 637.6 & \pm 434.7 & \pm 3.2 & \pm 7.9 \\
\hline \multirow[t]{2}{*}{$\mathrm{AAC} / \mathrm{C}[\%]$} & Mean & 26.5 & 15.5 & 10.8 & 33.9 & 32.7 & 10.1 & 2.8 \\
\hline & SD & \pm 8.6 & \pm 4.2 & \pm 5.9 & \pm 12.6 & \pm 10.5 & \pm 6.5 & \pm 2.6 \\
\hline \multirow{2}{*}{$\mathrm{AAN} / \mathrm{N}[\%]$} & Mean & 57.0 & 38.3 & 24.2 & 65.6 & 61.6 & & \\
\hline & $\mathrm{SD}$ & \pm 14.8 & \pm 8.8 & \pm 12.8 & \pm 18.4 & \pm 26.4 & & \\
\hline \multirow[t]{2}{*}{ Asp / $\beta$-Ala } & Mean & 71.8 & 19.2 & 10.5 & 57.9 & 47.3 & 10.2 & 2.6 \\
\hline & SD & \pm 63.4 & \pm 19.5 & \pm 6.6 & \pm 64.7 & \pm 44.9 & \pm 14.7 & \pm 2.4 \\
\hline \multirow[t]{2}{*}{ Glu $/ \gamma$-Aba } & Mean & 45.7 & 12.9 & 8.5 & 103.6 & 105.3 & 8.5 & 8.8 \\
\hline & $\mathrm{SD}$ & \pm 38.8 & \pm 7.2 & \pm 6.9 & \pm 122.7 & \pm 69.6 & \pm 7.0 & \pm 10.2 \\
\hline \multirow[t]{2}{*}{$\mathrm{AA} / \mathrm{HA}$} & Mean & 25.4 & 14.9 & 9.1 & 84.6 & 204.6 & 80.2 & 106.8 \\
\hline & $\mathrm{SD}$ & \pm 14.7 & \pm 6.6 & \pm 4.6 & \pm 42.7 & \pm 179.1 & \pm 65.2 & \pm 142.7 \\
\hline \multirow[t]{2}{*}{ Gluam / Galam } & Mean & 3.2 & 3.6 & 1.2 & 3.0 & 2.1 & 1.6 & 0.3 \\
\hline & $\mathrm{SD}$ & \pm 3.3 & \pm 1.1 & \pm 0.3 & \pm 1.8 & \pm 1.7 & \pm 2.4 & \pm 0.2 \\
\hline \multirow[t]{2}{*}{ RI } & Mean & 15.1 & 3.9 & 1.8 & 18.8 & 15.7 & 1.6 & 0.9 \\
\hline & $\mathrm{SD}$ & \pm 16.4 & \pm 1.5 & \pm 2.2 & \pm 10.6 & \pm 8.3 & \pm 1.8 & \pm 0.7 \\
\hline \multirow[t]{2}{*}{ DI } & Mean & 0.9 & 0.3 & -0.5 & 1.0 & 1.1 & 2.1 & 1.5 \\
\hline & $\mathrm{SD}$ & \pm 0.8 & \pm 0.3 & \pm 0.8 & \pm 0.1 & \pm 0.3 & \pm 1.1 & \pm 0.9 \\
\hline \multirow[t]{2}{*}{ SDI } & Mean & 1.1 & 0.0 & -0.9 & 0.8 & 0.8 & -0.7 & -0.8 \\
\hline & SD & \pm 0.2 & \pm 0.2 & \pm 1.0 & \pm 0.2 & \pm 0.3 & \pm 0.4 & \pm 0.3 \\
\hline \multirow[t]{2}{*}{ RTI } & Mean & 0.7 & 0.1 & 0.6 & 0.2 & -1.0 & -2.8 & -2.7 \\
\hline & $\mathrm{SD}$ & \pm 0.3 & \pm 0.3 & \pm 0.4 & \pm 0.5 & \pm 0.4 & \pm 0.6 & \pm 0.4 \\
\hline \multirow[t]{2}{*}{ ox / anox } & Mean & 1.2 & 1.3 & 2.2 & 1.1 & 1.0 & 0.8 & 0.7 \\
\hline & SD & \pm 0.3 & \pm 0.2 & \pm 1.1 & \pm 0.1 & \pm 0.1 & \pm 0.3 & \pm 0.3 \\
\hline
\end{tabular}

* Definition of these indicators can be found in Sect. 4.2 below.

particles in the ocean. Sinking particles build up sediments, and the degradation pathways evident in the water column namely the accumulation of degradation products and acidic AA often absorbed to carbonates - continue in the sediments. Novel biogeochemical indicators are required for SPM and possibly also DOM to characterize their AA changes.

\subsection{Results of a PCA: two new biogeochemical indicators}

A PCA of individual AAs (Mol\%, Fig. 6a) of all samples compiled in this study results in two factors which explain $59 \%$ of the total variance within the data set. The first factor delineates the well-known changes along the degradation pathway from plankton via sinking particles to sediments. Phe, Ile, Leu, Glu, and Tyr (enriched in fresh plankton) have the highest F1 loadings while Asp, B-Ala, and $\gamma$-Aba (accumulating during degradation) have the lowest negative F1 loadings. The highest F2 loadings are found for Asp, Thr, Lys, and Val while Gly, Orn, His, and Ser have the most negative F2 loadings. Factor scores of the individual samples (Fig. 6b) plot in a triangular shape with plankton and fresh organic matter from surface waters at the apex with the highest F1 and F2 scores. The diverging sides of the triangle mark sinking particles and sediments decreasing in F1 scores on one side and SPM with decreasing F2 scores on the other side (Fig. 6b). Similar trends were observed in earlier studies based on local data sets (Nagel et al., 2016; Gaye et al., 2013b). That samples from greatly different environments reveal the same divergence between sinking particles and SPM with only little overlap (Fig. 4) suggests a general mechanism operating globally. Most of the overlap encompasses SPM and sediment trap samples from the Kara Sea all sampled at water depths below $100 \mathrm{~m}$. The Kara Sea is characterized by sediment resuspension related to strong river- 
ine input in combination with sea ice dynamics so that many of the Kara Sea SPM and trap samples are mixed with resuspended sediments (Gaye et al., 2007; Unger et al., 2005). TDAAs analyzed in water and pore water form a cluster with significantly different AA composition from particulate matter, but instead recapitulating the enrichments of Mol \% Ser, His, and Orn observed in SPM (Fig. 6b).

The precise separation of the degradation pathway of sinking particles and sediments from SPM and DOM by the PCA suggests that we can use the first factor (F1) to calculate a new sinking particle and sediment degradation index (SDI):

$\mathrm{SDI}=\sum_{i}\left(\frac{\operatorname{var}_{i}-\mathrm{AVG}_{\mathrm{Var}}}{\mathrm{SD} \cdot \operatorname{var}_{i}}\right) \times$ Loadings.F1 $_{i}$,

where $\operatorname{var}_{i}$ is the original mole percentage of each $\mathrm{AA}_{i}$; AVG.var ${ }_{i}$ and STD.var $i$ are the mean and standard deviations, respectively; and Loadings.F $1_{i}$ is the factor loading of the first axis (F1) of the PCA of the individual amino $\operatorname{acid}_{i}$ shown in Table 2. Most of the F1 loadings resemble those of the DI of Dauwe et al. (1999) (Table 2), and the SDI and DI are thus significantly correlated (Table 3 ).

The second factor (F2) - normalized in the same way with the averages and standard deviations of the same PCA - can be used as an indicator of changes in the AA composition of SPM possibly related to the residence time or renewal time of the water mass they are transported with (see discussion in Sect. 4.2.2). With longer residence time in the ocean, the organic matter in SPM is likely to become more recalcitrant and the indicator and is therefore named residence time index (RTI),

$\mathrm{RTI}=\sum_{i}\left(\frac{\operatorname{var}_{i}-\mathrm{AVG}_{\mathrm{Var}}}{\mathrm{SD} \cdot \operatorname{var}_{i}}\right) \times$ Loadings.F2 $_{i}$,

and is calculated in the same way as the SDI, but the factor loadings of the second axis (F2) of the PCA of the individual $\operatorname{amino} \operatorname{acid}_{i}$ (Table 2) are inserted for the term Loadings.F2 $i$.

The SDI allows a separation of trap samples from shallow water depth from those of greater depths (Fig. S1). All samples from deep sediment traps have SDI values below 0.5. Likewise, SPM from $>200 \mathrm{~m}$ depths has lower RTI than most of the samples from shallower depths. Deep trap samples and deep SPM samples form two clearly separated clusters with different SDI and RTI (see Fig. S1 for further details).

\subsubsection{The SDI as an indicator of degradation and oxic vs. anoxic diagenetic conditions of sinking particles and sediments}

In order to test the performance of our new degradation indices, we separated SPM samples from sinking particles and sediments and correlated the common biogeochemical indicators and individual AAs (Mol\%) of SPM with the RTI of individual samples while we correlated the same variables
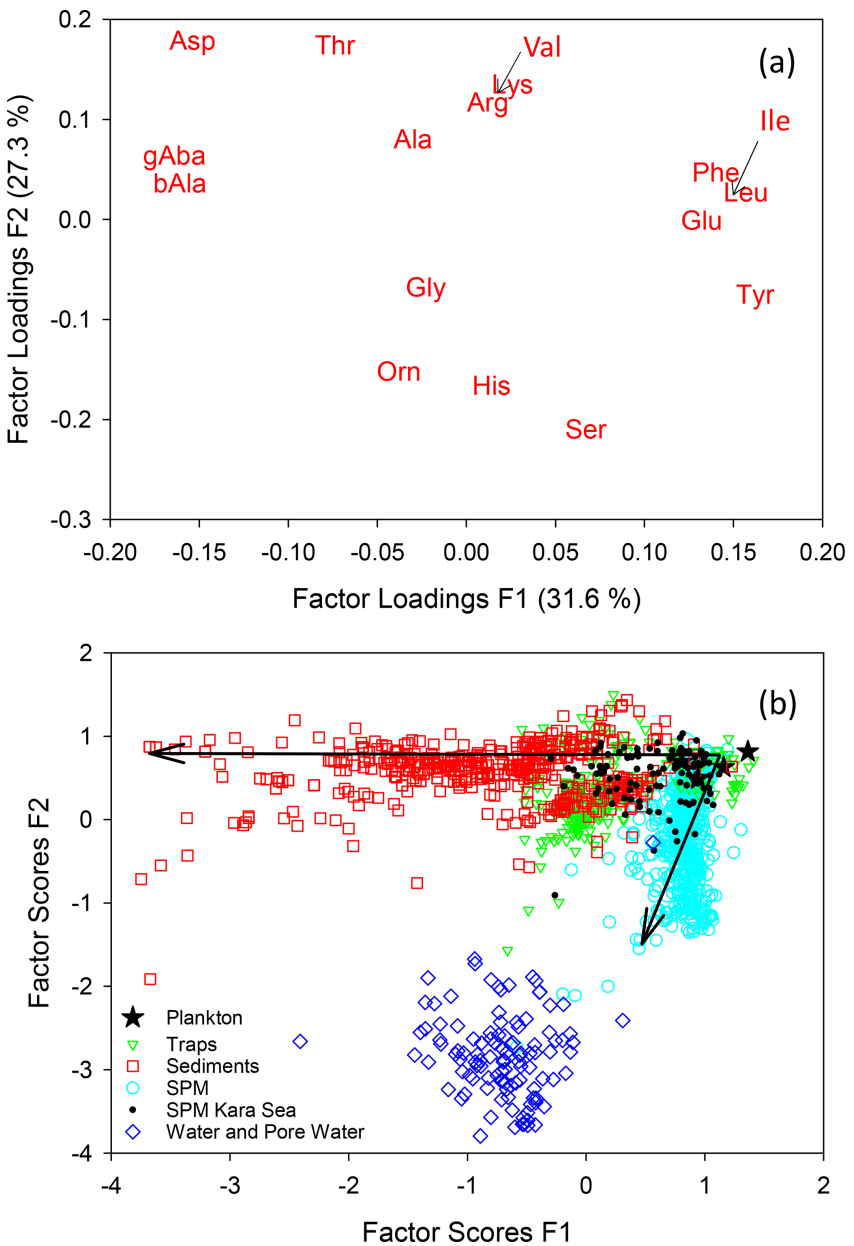

Figure 6. Results of a PCA of AAs (Mol\%) of all samples of this study with factor loadings of amino acids for the first and second factors (a) and factor scores of samples (b). Small arrows in (a) point to the positions of Val and Ile. Arrows in (b) indicate progressive deviation in composition from the plankton source, essentially with increasing water and sediment depths.

of sinking particles and sediments with the SDI (Table 3). We assume that correlations with Pearson correlation coefficients $R>0.50$ can be considered "strong correlations" (Cohen, 1988). The SDI correlates moderately to strongly with the common degradation indicators, and the best positive correlation is found between SDI and the DI (Table 3). The strong correlation among the degradation indicators with POC contents indicates that this common and often measured variable is a good indicator of relative organic matter quality in sinking particles and sediments, and all other degradation indices do not perform better than POC concentrations (see correlation coefficients in Table 3). The DI and the SDI, which are to some extent interchangeable, allow a fine tuning of degradation intensities. The most significant negative correlation of the ox / anox ratio with the SDI is preconditioned, as the ox / anox is the quotient of AAs enriched by degrada- 
Table 2. Factor loadings of F1 and F2 for calculating the SDI and RTI, respectively, average [Mol \%] and standard deviations (SD) of AAs of samples used for the PCA shown in Fig.6 in comparison with the factor loadings (named factor coefficients) of the DI published by Dauwe et al. (1999), and their averages [Mol\%] and standard deviations used for the DI based on 28 sediment samples.

\begin{tabular}{lrrrrrrr}
\hline Amino acid & $\begin{array}{r}\text { Loadings F1 } \\
\text { SDI }\end{array}$ & $\begin{array}{r}\text { Average } \\
{[\text { Mol \% }]}\end{array}$ & SD & $\begin{array}{r}\text { Loadings F2 } \\
\text { RTI }\end{array}$ & DI & $\begin{array}{r}\text { DI average } \\
{[\text { Mol } \%]}\end{array}$ & DI SD \\
\hline Ser & 0.067 & 8.7 & 3.6 & -0.210 & 0.015 & 7.2 & 1.9 \\
His & 0.014 & 2.4 & 2.3 & -0.166 & 0.158 & 1.0 & 0.8 \\
Orn & -0.038 & 1.2 & 1.9 & -0.152 & - & - & - \\
Tyr & 0.162 & 1.9 & 1.1 & -0.075 & 0.178 & 2.1 & 1.2 \\
Gly & -0.023 & 16.2 & 2.8 & -0.068 & -0.099 & 17.6 & 3.8 \\
Glu & 0.132 & 10.5 & 2.5 & -0.001 & 0.065 & 10.0 & 2.3 \\
Leu & 0.157 & 5.9 & 1.9 & 0.027 & 0.169 & 6.6 & 1.5 \\
Ile & 0.148 & 3.8 & 1.0 & 0.028 & 0.139 & 4.5 & 0.8 \\
$\beta$-Ala & -0.161 & 1.3 & 2.0 & 0.036 & - & - & - \\
Phe & 0.140 & 2.9 & 1.0 & 0.047 & 0.134 & 3.2 & 1.2 \\
$\gamma$-Aba & -0.164 & 1.0 & 1.6 & 0.064 & - & - & - \\
Ala & -0.030 & 9.1 & 1.5 & 0.080 & -0.043 & 11.8 & 0.8 \\
Arg & 0.012 & 4.2 & 1.1 & 0.117 & -0.115 & 6.1 & 2.3 \\
Val & 0.020 & 5.7 & 1.1 & 0.132 & -0.044 & 7.6 & 1.1 \\
Lys & 0.026 & 5.1 & 1.2 & 0.135 & - & - & - \\
Thr & -0.074 & 5.7 & 1.2 & 0.174 & -0.129 & 7.1 & 1.5 \\
Asp & -0.154 & 12.2 & 4.3 & 0.179 & -0.102 & 13.4 & 2.7 \\
\hline
\end{tabular}

tion to those enriched in fresh plankton. It should be noted that this negative correlation is even better than the positive correlation of the DI and the SDI. A close look at the SDI and ox / anox in sediment samples suggests that the SDI can be used to distinguish between oxic and anoxic diagenetic conditions (Fig. 7). The sediment samples deposited in regions of bottom water anoxia (surface samples from Namibian shelf at $<200 \mathrm{~m}$ depths; a core from the Arabian Sea slope at $775 \mathrm{~m}$ ) have lower ox / anox ratios and distinctly higher SDI values compared with the samples from similar depths and oxygenated bottom water (e.g., Mediterranean Sea, Kara Sea) (Fig. 7a). The SDI performs better than the DI to determine diagenetic conditions as the DI less significantly correlates with the ox / anox indicator (Fig. S2). The best fit between the SDI and the ox / anox in sediment samples is an exponential correlation with a correlation coefficient of $R=-0.95$ while the DI and the ox / anox correlate exponentially with an $R=-0.79$ (Figs. 7a, S2). The SDI better depicts the spectral changes in samples deposited under anoxic diagenetic conditions such as those from the Namibian shelf (Nagel et al., 2016) and the Arabian Sea mid-water oxygen minimum zone (Suthhof et al., 2001) while the ox / anox ratio better resolves variations in samples of strong oxic degradation so that the SDI is in fact better suited to determine the threshold of anoxic vs. oxic diagenesis. Another indication of this quality of the SDI is that the anoxic sediments have SDI values in the range of sediment trap samples from the water column while the SDI decreases in sediments under oxic diagenetic conditions (Fig. 7b). Further, the SDI also correlates with other indicators of oxic vs. anoxic conditions. The core SO90-111 KL from within the mid-water oxygen minimum impinging on the Pakistan margin was used to reconstruct changes in oxygenation during the last $60 \mathrm{kyr}$ based on $\delta^{15} \mathrm{~N}$ values of total $\mathrm{N}$ (Suthhof et al., 2001). The $\delta^{15} \mathrm{~N}$ values fluctuated between enhanced values in warm phases due to denitrification in the mid-water oxygen minimum and lower values in cold phases when the oxygen minimum zone was weaker or absent (Suthhof et al., 2001). The SDI very precisely tracks these changes (Fig. 7c), and in accordance with the threshold discernable in Fig. 7a and b, we propose that the divide between oxic and anoxic diagenetic conditions is at SDI values between 0 and -0.2 , with SDI $<-0.2$ indicating oxic and SDI $>0$ indicating anoxic diagenetic conditions (Fig. 7a, b). We further propose to use this indicator to reconstruct redox conditions from sediment cores. The work of Carr et al. (2016) - relying on the DI - suggests that signals of changes in redox conditions can be preserved even down to $200 \mathrm{~m}$ core depth.

\subsubsection{The RTI as an indicator of suspended matter residence time}

Changes in SPM composition between shallow and deep waters (Fig. 4b) are depicted by a decrease in the RTI, which is due to the relative depletion of Asp, Thr, Lys, and Val with the highest positive factor loadings and the enrichment of Ser, His, and Orn with the most negative factor loadings (Table 2). Both Ser and Gly (Mol \%) are strongly linearly anticorrelated with the RTI ( $R=-0.91$ and -0.90$)$, showing that they can be used instead of the RTI to characterize SPM if not all AAs used for the RTI can be measured. The anticor- 
Table 3. Pearson correlation coefficients of the SDI, RI, DI, Asp / $\beta$-Ala, and Glu / $\gamma$-Aba with selected AA*, the RTI, AAC / C, AAN / N, AA ratios and degradation indices, water depth (Depth), POC and TN contents (\%), and AA concentrations (nmol $\mathrm{g}^{-1}$ ) in sediment trap and sediment samples (columns 2-6). Pearson correlation coefficients of the RTI, RI, DI, Asp / $\beta$-Ala and Glu / $\gamma$-Aba with selected AA, SDI, AAC / C, AAN / N, AA ratios and degradation indices, water depth (Depth), POC and TN contents (\%), and AA concentrations (nmol $g^{-1}$ ) in SPM samples (columns 8-12). Italics indicate strong correlation.

\begin{tabular}{|c|c|c|c|c|c|c|c|c|c|c|c|}
\hline 1 & 2 & 3 & 4 & 5 & 6 & 7 & 8 & 9 & 10 & 11 & 12 \\
\hline Traps, sediments & SDI & RI & DI & Asp / $\beta$-Ala & Glu / $\gamma$-Aba & SPM & RTI & RI & DI & Asp / $\beta$-Ala & Glu / $\gamma$-Aba \\
\hline Asp & -0.68 & -0.30 & -0.83 & -0.25 & -0.32 & Asp & 0.81 & 0.00 & -0.61 & 0.13 & -0.17 \\
\hline Thr & 0.12 & -0.25 & -0.25 & 0.03 & 0.07 & Thr & 0.86 & -0.02 & -0.57 & 0.06 & -0.16 \\
\hline Ser & 0.32 & 0.03 & 0.16 & 0.09 & 0.16 & Ser & -0.91 & -0.15 & 0.08 & -0.11 & -0.01 \\
\hline Gly & -0.21 & -0.32 & -0.45 & -0.31 & -0.31 & Gly & -0.90 & -0.17 & 0.12 & -0.11 & 0.04 \\
\hline Ala & 0.46 & 0.07 & 0.17 & 0.03 & 0.11 & Ala & 0.91 & 0.09 & -0.43 & 0.11 & -0.09 \\
\hline Val & 0.67 & 0.31 & 0.48 & 0.29 & 0.31 & Val & 0.88 & 0.07 & -0.26 & 0.08 & -0.09 \\
\hline Ile & 0.87 & 0.48 & 0.76 & 0.52 & 0.55 & Ile & 0.68 & 0.34 & 0.26 & 0.26 & 0.02 \\
\hline Leu & 0.88 & 0.49 & 0.76 & 0.52 & 0.56 & Leu & 0.65 & 0.47 & 0.28 & 0.35 & 0.11 \\
\hline Tyr & 0.72 & 0.39 & 0.76 & 0.34 & 0.32 & Tyr & -0.14 & 0.27 & 0.66 & 0.02 & 0.23 \\
\hline Phe & 0.89 & 0.38 & 0.79 & 0.40 & 0.44 & Phe & 0.78 & 0.37 & 0.04 & 0.29 & 0.06 \\
\hline$\beta$-Ala & -0.85 & -0.27 & -0.44 & -0.32 & -0.35 & $\beta$-Ala & -0.08 & -0.66 & -0.19 & -0.52 & -0.12 \\
\hline$\gamma$-Aba & -0.79 & -0.25 & -0.37 & -0.28 & -0.35 & $\gamma$-Aba & 0.24 & -0.53 & -0.65 & -0.20 & -0.40 \\
\hline Lys & 0.56 & 0.14 & 0.43 & 0.15 & 0.15 & Lys & 0.71 & 0.05 & -0.20 & 0.03 & -0.06 \\
\hline SDI & & 0.45 & 0.82 & 0.46 & 0.51 & SDI & 0.07 & 0.49 & 0.83 & 0.23 & 0.28 \\
\hline RTI & 0.04 & -0.01 & -0.26 & 0.03 & -0.05 & RTI & & 0.10 & -0.34 & 0.12 & -0.08 \\
\hline $\mathrm{AAC} / \mathrm{C} \%$ & 0.56 & 0.51 & 0.53 & 0.56 & 0.56 & $\mathrm{AAC} / \mathrm{C} \%$ & -0.08 & 0.14 & 0.22 & 0.06 & 0.09 \\
\hline AAN / N\% & 0.55 & 0.40 & 0.49 & 0.47 & 0.47 & $\mathrm{AAN} / \mathrm{N} \%$ & -0.05 & 0.06 & 0.03 & -0.06 & 0.08 \\
\hline $\mathrm{AA} / \mathrm{HA}$ & 0.54 & 0.58 & 0.54 & 0.73 & 0.75 & AA / HA & -0.57 & 0.11 & 0.32 & -0.01 & 0.16 \\
\hline Gluam / Galam & 0.36 & 0.43 & 0.44 & 0.40 & 0.35 & Gluam / Galam & 0.27 & 0.43 & 0.16 & 0.28 & 0.08 \\
\hline Asp / $\beta$-Ala & 0.46 & 0.93 & 0.57 & & 0.85 & Asp / $\beta$-Ala & 0.12 & 0.74 & 0.10 & & 0.07 \\
\hline Glu / $\gamma$-Aba & 0.51 & 0.93 & 0.56 & 0.85 & & Glu / $\gamma$-Aba & -0.08 & 0.37 & 0.24 & 0.07 & \\
\hline RI & 0.45 & & 0.49 & 0.93 & 0.93 & RI & 0.10 & & 0.33 & 0.74 & 0.37 \\
\hline DI & 0.82 & 0.49 & & 0.51 & 0.56 & DI & -0.34 & 0.33 & & 0.10 & 0.24 \\
\hline ox / anox & -0.91 & -0.30 & -0.71 & -0.31 & -0.37 & ox / anox & 0.67 & -0.19 & -0.50 & -0.10 & -0.09 \\
\hline Depth & -0.67 & -0.28 & -0.54 & -0.28 & -0.37 & Depth & -0.55 & -0.12 & 0.23 & -0.11 & 0.04 \\
\hline $\mathrm{POC}$ & 0.57 & 0.79 & 0.67 & 0.77 & 0.76 & POC & 0.27 & 0.30 & 0.13 & 0.25 & -0.03 \\
\hline $\mathrm{N}$ & 0.45 & 0.46 & 0.50 & 0.39 & 0.39 & $\mathrm{~N}$ & 0.29 & 0.30 & 0.13 & 0.24 & -0.01 \\
\hline AA & 0.51 & 0.84 & 0.60 & 0.79 & 0.76 & AA & 0.17 & 0.28 & 0.15 & 0.20 & 0.01 \\
\hline
\end{tabular}

* Only AAs with a correlation coefficient $R \geq 0.50$ with at least one of the indicators are shown.

relation of the RTI with water depths $(R=-0.55$; Table 3$)$ is due to the RTI decrease in the upper 200 m only. Below this depth there is no further trend in the RTI, and values scatter between -0.5 and -1.5 (Fig. 8).

The results of our PCA also show that below $200 \mathrm{~m}$ SPM becomes distinctly decoupled from sinking aggregates (Figs. 6, S1). Both sinking particles and SPM sampled in the upper ocean mixed layer and euphotic zone resemble fresh plankton, whereas below the surface mixed layer they follow different pathways, and the chance that SPM and sinking particles interact obviously decreases with water depth, which could be due to the scarcity of both types of particles in the deep ocean (McCave, 1984). Our AA results support previous studies on SPM (using thorium isotopes, radiocarbon, and biomarkers, for example) which found that the interaction between sinking particles and SPM by aggregation and disaggregation strongly decreases from the euphotic zone to the meso- and bathypelagic zone and that SPM rather interacts with DOM due to the long residence time of both in the deep ocean (Lam and Marchal, 2015). The observed constant AA composition of SPM below $200 \mathrm{~m}$ water depth could be explained by a recalcitrant nature making the AAs barely accessible to further microbial degradation. Alternatively, and analogously with observations of DOC, it could be due to low concentrations of SPM, which rather than their recalcitrance limit prokaryotic growth and thus organic matter degradation in the deep ocean (Arrieta et al., 2015). The age of the water masses in the upper ocean mixed layer is less than 100 years while deeper waters have ages of several 100 years to maxima of 1600 years in the deep Indian and Pacific oceans (England, 1995; Gebbie and Huybers, 2012). The constantly low RTI below the mixed layer is thus related to the long residence time of deep SPM in the deep ocean. An earlier study using detailed ventilation ages available from the Atlantic and Pacific subtropical gyres at stations BATS and respectively HOT showed that changes in AA composition of SPM took place within a few decades (Kaiser and Benner, 2009).

Solubilization of particulate matter by exoenzymes and the subsequent uptake in the dissolved form (Carlson and Hansell, 2015; Aristegui et al., 2009) lead to an almost complete turnover of originally diverse surface-derived organic 

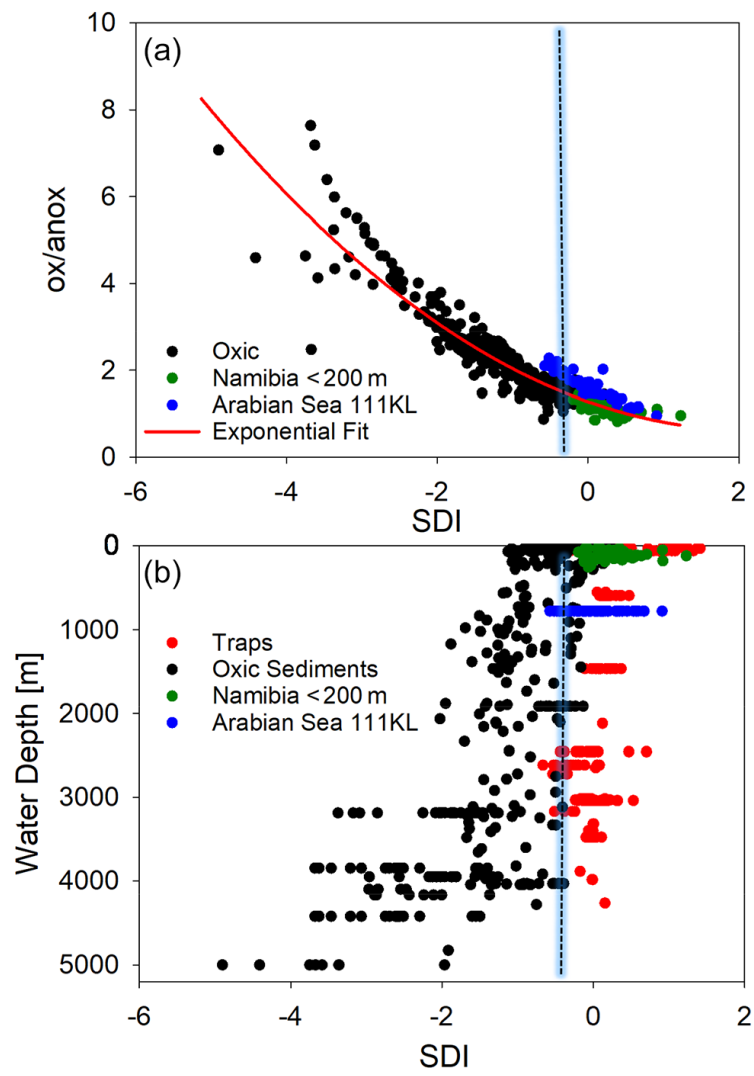

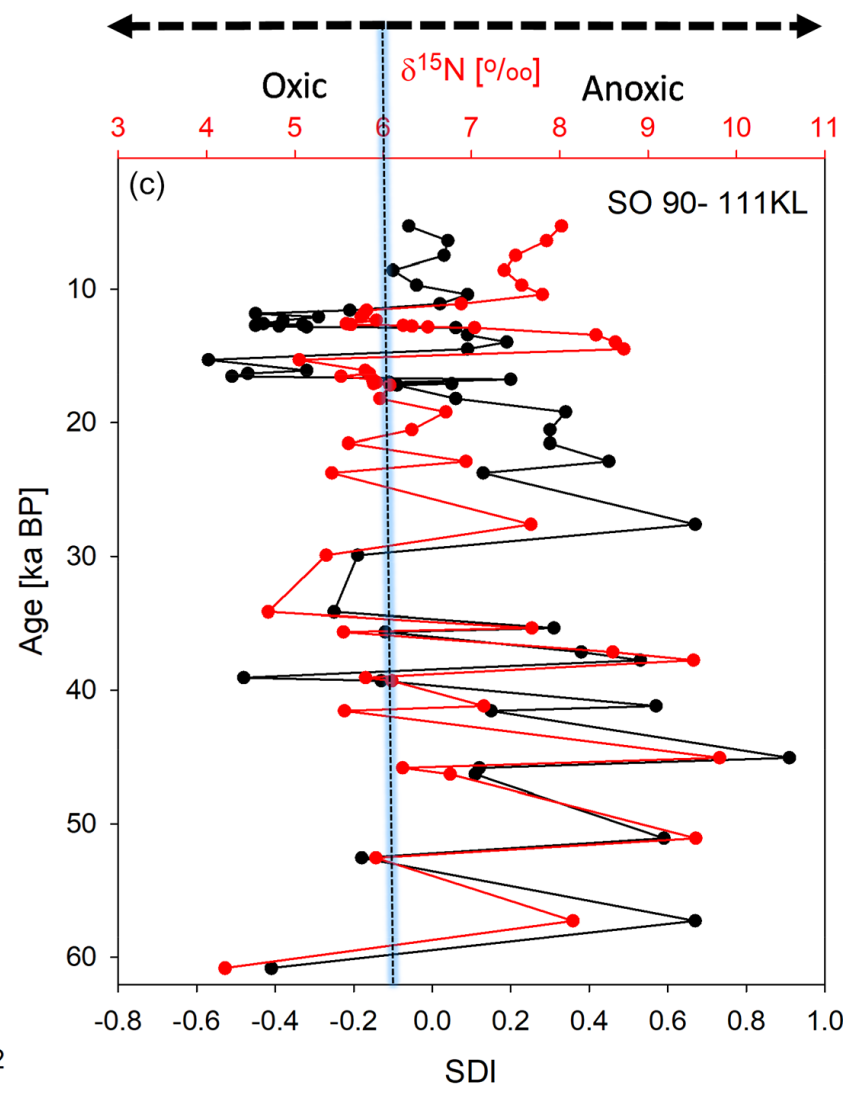

Figure 7. SDI indicator plotted against the ox / anox ratio, with dots indicating oxic sediments (black) and suboxic to anoxic sediments from Namibia (green) and the Arabian Sea (blue). The red line marks the exponential fit to all sediment samples with an $R=0.95$ (a). SDI plotted with water depth (in meters) of sediment trap deployment (red) and of sediment sampling (see color code of a) (b). SDI and the $\delta^{15} \mathrm{~N}$ of total $\mathrm{N}$ with sediment depth in sediment core SO90-111 KL correlated with an $R=0.71$ (c); the blue bar marks the threshold of the SDI delimiting oxic and anoxic diagenetic conditions at an SDI value of about -0.1 .

matter. It is thus feasible that bacterial biomass comprises a large amount of organic matter in compartments of long residence times. However, fresh bacteria and fungi have quite similar AA composition as plankton (Cowie and Hedges, 1992) while SPM AA composition is fundamentally different. The high AA / HA ratios not having a clear trend with water depth also suggest that the contribution of bacterial biomass to SPM is small and does not increase with water depth (Table 1; Fig. 5a, b). The observed changes in SPM are thus more likely related to adsorption processes and macromolecule formation of material not digestible to deep sea organisms and resistant to their enzymes. DOM was shown to become adsorbed to mineral surfaces (Keil and Kirchman, 1993, 1994; Keil et al., 1994; Arnarson and Keil, 2005, 2007). However, degradation of adsorbed AA proceeds on particles (Satterberg et al., 2003; Taylor, 1995). Thus, the constant AA composition in SPM at depths $>200 \mathrm{~m}$ may indicate that SPM is in equilibrium with TDAAs, which likewise show no clear depth-dependent changes in AA composition (Figs. S3, S4). Feasible candidate processes to explain the homogeneity are AA scavenging by SPM or for- mation of gels (3D networks = biopolymers), which can anneal to larger sizes so that part of the dissolved AA can be passed from the dissolved to the particulate organic carbon pool (Druffel and Williams, 1990; Orellana and Leck, 2015). This process is, however, reversible so that there is probably an exchange between the gel and particulate matter phase as well as between gels of different sizes and complexities depending on $\mathrm{pH}$, temperature, the presence of ligands, pollutants, or UV radiation (Orellana and Leck, 2015). Generally, hydrophobic AAs (Ala, Val, Met, Ile, Leu, Phe, Pro, Trp) and aromatic AAs (His, Tyr) are more likely to form gels and aggregates (Orellana and Leck, 2015). Our results indicate that an equilibrium may be attained between the dissolved phase and SPM after a relatively short time so that the AA composition of SPM is constant below $200 \mathrm{~m}$ water depth. If there is no further significant scavenging of SPM by sinking particles and no degradation of AA on SPM, their abundance could increase due to further adsorption of DOM with increasing age on the ocean conveyer belt. However, large zooplankters may be able to utilize the SPM pool (Koppelmann et al., 2009; Gloeckler et al., 2018; Hannides et al., 2013), 
and further studies are required to elucidate the fate of SPM in the ocean.

\subsection{Contents and composition of total dissolved amino acids in sea water and pore water}

The TDAA concentrations show a decrease from the epipelagic to the mesopelagic ocean similar to many earlier findings (Davis et al., 2009; Kaiser and Benner, 2009; Kim et al., 2017), whereas the spectra of TDAA sampled in the oligotrophic Indian Ocean Subtropical Gyre and the deep Pacific are uniform with water depth. This is also reflected in the DOM-DI, which does not show any trend with either depth in the water column or in sediments (Fig. S4). Further, the difference between water and pore water samples is small, and Ser, Gly, and His are uniformly the major TDAAs in sea water and pore water. It is possible that the selective accumulation of these AAs in the dissolved phase is due to their excretion or their association with exoenzymes. Ser is present in $N$-acyl homoserine lactone (AHL), which is a class of bacterially produced signaling molecules involved in bacterial quorum sensing; these compounds serve to regulate growth by changing gene expressions, for example, in order to influence population density or phenotype (Parsek et al., 1999; Klein et al., 2009). His changes from its protonated to deprotonated form at a $\mathrm{pH}$ of 6 and is therefore often present at the active sites of enzymes. Ser and Gly may simply remain dissolved in sea water as they are hydrophilic. Once mixed into the deeper ocean the scarcity of bacteria or the incorporation of AA into gels could be the reason for their recalcitrance. However, we do not assume that a considerable part of the TDAA belong to dissolved free AA. Because the differences between samples from different regions are much smaller than the difference between the molecular weight fractions and sea water vs. pore water (Fig. S3), we surmise that the formation and transformation processes of DOC are very uniform in the ocean. This assumption is based on limited data so that these results are rather preliminary. We also do not have enough spatial coverage of SPM and TDAA data in the deep ocean to detect AA utilization by organisms or sorption and desorption processes. Both these organic matter pools are large (see below), so that such investigations are important to estimate the possible role of these pools in oceanic carbon sequestration and the reactions to global change (Ridgewell and Arndt, 2015; Lonborg et al., 2018).

Our AA yield of DOC with AA-C / C of $10.1 \pm 6.5 \%$ is in the high range of studies from the literature. In some of the previous studies AAC / C was between $0.4 \%$ and $4 \%$ with a reduction from $1 \%-4 \% \mathrm{AAC} / \mathrm{C}$ in surface waters to $0.4 \%-$ $0.8 \%$ in waters $>1.000 \mathrm{~m}$. This reduction was moreover associated with a progressive AA degradation reflected in the DI and the DOM-DI at some of the sampling stations (Kim et al., 2017; Davis and Benner, 2005; Kaiser and Benner, 2009). These lower yields may however be due to different hydrol- ysis conditions as these studies used water vapor hydrolysis at higher temperatures $\left(150^{\circ} \mathrm{C}\right)$ but for a much shorter duration (32.5 min). Studies using the same hydrolysis conditions as this work reported AAC / C of 5\%-10\% (Ittekkot, 1981; Keil and Kirchman, 1999; McCarthy et al., 1997).

\section{$4.4 \delta^{15} \mathrm{~N}$ values in sinking and suspended matter and evidence for nitrogen sources and transformation processes}

The $\delta^{15} \mathrm{~N}$ values in sediments can preserve information on $\mathrm{N}$ sources throughout the geological history (Sun et al., 2019; Gaye et al., 2018; Kienast et al., 2008). However, $\delta^{15} \mathrm{~N}$ values may be modulated by organic matter cycling and diagenetic processes which are replicated and thus traceable in the AA composition not least because AAs are the main identifiable contributors to $\mathrm{N}$ in particulate organic matter. The increase in $\delta^{15} \mathrm{~N}$ values by about $2 \%$ on average during organic matter burial and early diagenesis in the upper sediments (Robinson et al., 2012; Tesdal et al., 2013) is corroborated by a parallel shift in AA-based degradation indicators (Gaye-Haake et al., 2005; Möbius et al., 2010). In contrast to sediments, there are no clear depth-related trends in $\delta^{15} \mathrm{~N}$ values of sinking particles in the water column of the epito mesopelagic ocean (Gaye-Haake et al., 2005; Yang et al., 2017; Altabet, 2006). AA-based biogeochemical indicators revealed degradation with depth at specific trap sites (Haake et al., 1993a), and $\delta^{15} \mathrm{~N}$ analyses of individual amino acids showed that degradation is proceeding on sinking particles with $\delta^{15} \mathrm{~N}$ changes of "trophic" AA while $\delta^{15} \mathrm{~N}$ of "source" AA remained constant (McCarthy et al., 2007). However, degradation of sinking particles is much smaller than degradation at the sediment-water interface. In our large data set that integrates many different areas of study the small to moderate changes in AA degradation are obviously obliterated, as neither AA concentrations (Fig. 3) nor the SDI (Fig. 7), the AAC /C (Fig. S5), and the AAN / N\% (not shown) reveal any significant trends in sinking particles in the deep ocean.

AA composition of SPM as expressed in the RTI is constant, and SPM is rather recalcitrant at water depths $>200 \mathrm{~m}$. Paralleling this, the $\delta^{15} \mathrm{~N}$ values of SPM are about $6 \%$ - $8 \%$ o on average in all our studies carried out (Fig. 8). In previous studies $\delta^{15} \mathrm{~N}$ values of SPM were reported to increase from $\leq 5 \%$ in surface waters to values between $6 \%$ - $8 \%$ o below $200 \mathrm{~m}$ water depth, which was attributed to organic matter degradation on SPM (Yang et al., 2017; Altabet et al., 1991; Hannides et al., 2013; Emeis et al., 2010). However, SPM samples from the Arabian Sea upwelling area show decreasing $\delta^{15} \mathrm{~N}$ values from an average of $8.6 \%$ at water depth above $200 \mathrm{~m}$ to $7.4 \%$ at depths below $200 \mathrm{~m}$ (Gaye et al., $2013 b)$. It is thus reasonable that SPM has a constant $\delta^{15} \mathrm{~N}$ value in the mesopelagic and bathypelagic ocean. This is an additional indicator of a common process determining the AA composition and their $\delta^{15} \mathrm{~N}$ values of SPM and probably 


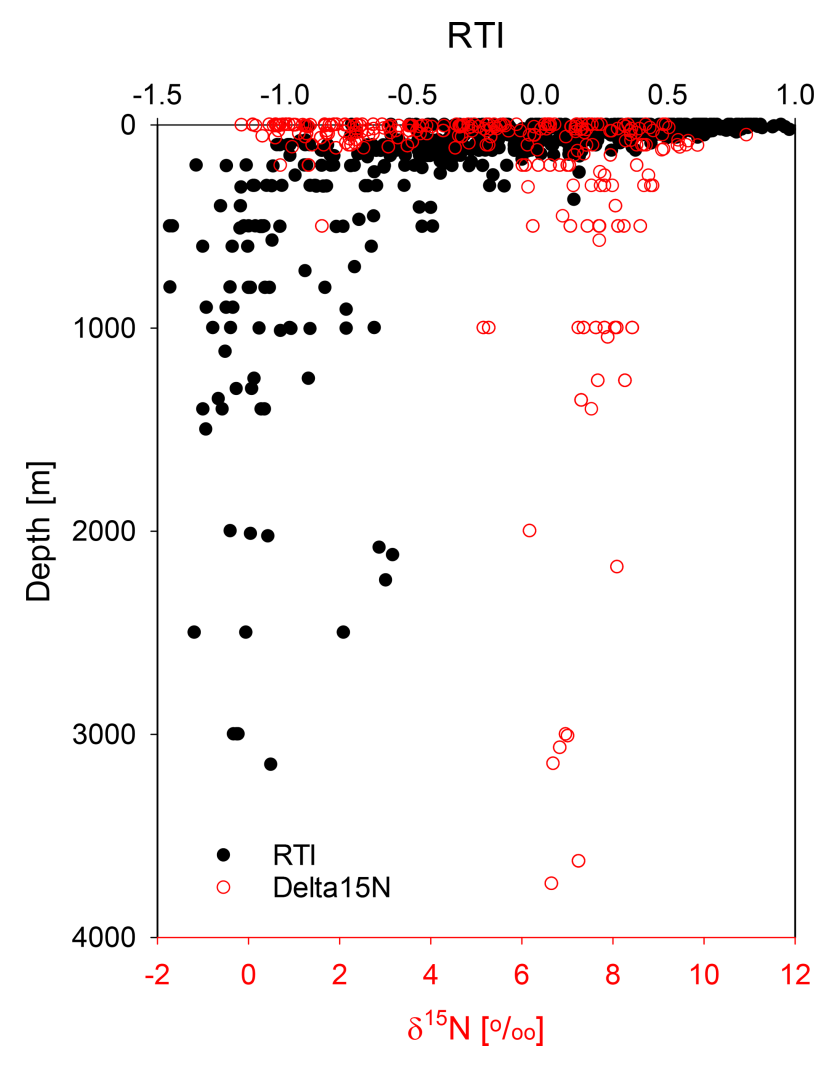

Figure 8. The RTI (black dots) and the $\delta^{15} \mathrm{~N}$ values of SPM with water depths $(\mathrm{m})$ (red circles).

also of DOM sampled below water depths of $200 \mathrm{~m}$ (equivalent to an age of $\geq 100$ years; England, 1995; Gebbie and Huybers, 2012).

\subsection{Abundance of amino acids in the ocean}

Based on POC, TN, and AA fluxes and the area of the open ocean and shallow seas (Costello et al., 2010), we can estimate annual downward fluxes (Table S6). Average POC flux of compilations of trap fluxes were between $1.65 \mathrm{~g} \mathrm{~m}^{-2} \mathrm{a}^{-1}$ (Wilson et al., 2012) and $2.74 \mathrm{~g} \mathrm{~m}^{-2} \mathrm{a}^{-1}$ (Rixen et al., 2019a) while our subset of trap samples from the open ocean (> $2000 \mathrm{~m}$ water depth) averages to $3.06 \mathrm{~g} \mathrm{~m}^{-2} \mathrm{a}^{-1}$. For open ocean traps this results in total fluxes of $0.51-0.94 \mathrm{Pg} \mathrm{Ca}^{-1}$. Our average flux estimates for $\mathrm{TN}$ are $0.13 \mathrm{PgN} \mathrm{a}^{-1}$ and for AAC are $0.15 \mathrm{Pg} \mathrm{AA} \mathrm{a}^{-1}$. The flux rates over the shelves and slopes bear, however, large uncertainty because productivity is higher by several orders of magnitude than in offshore areas and spatially variable. Our first estimate, simply based on an average of our fluxes caught in traps deployed in areas of water depth $<2000 \mathrm{~m}$ arrives at POC fluxes of 5.4 $\mathrm{Pg} \mathrm{Ca}^{-1}$, TN fluxes of $0.9 \mathrm{Pg} \mathrm{N} \mathrm{a}^{-1}$, and AAC fluxes of $1.36 \mathrm{Pg} \mathrm{AAC} \mathrm{a}^{-1}$. Thus $85 \%-90 \%$ of fluxes occur in nearshore environments, corroborating that $95 \%$ of the total marine organic carbon is buried in these environments (Hedges and Keil, 1995). The total sinking fluxes in the proximal plus distal ocean add up to $6.3 \mathrm{PgCa}^{-1}, 1.0 \mathrm{Pg} \mathrm{Na}^{-1}$, and, respectively, $1.51 \mathrm{Pg} \mathrm{AAC} \mathrm{a}^{-1}$ (see Table S6 for further details).

The largest organic carbon pool in the ocean is DOC with an inventory of $632 \pm 32 \mathrm{Pg} \mathrm{C}$ (Carlson and Hansell, 2015; Hansell et al., 2009), and the largest $\mathrm{N}$ pool is DON with $77 \pm 23$ Pg N (Gruber, 2008; Bronk, 2002). Dissolved AAs are thus the largest AA pool in the ocean even if AAs comprise only a minor amount of DOC. We have only a few measurements of AA concentrations, which range between $0.1-0.2 \mathrm{mg} \mathrm{L}^{-1}$ with an average of $0.16 \mathrm{mg} \mathrm{L}^{-1}$ in all water samples excluding bottom water. Based on these data we can estimate that AAs comprise about $200 \pm 70 \mathrm{Pg}$, which would contribute about $35 \pm 11 \mathrm{Pg}$ AAN and about $89 \pm 29 \mathrm{Pg}$ AAC to the oceanic DON and, respectively, DOC pools. Accordingly, AAC contributes about $14 \%$ to DOC while AAN contributes $45 \%$ to total oceanic DON. This is in the low range of an estimate of $45 \%-86 \%$ AAN based on nuclear magnetic resonance (NMR) spectroscopy with acid hydrolysis suggested to recover about half of this AAN pool (Aluwihare et al., 2005).

The constant composition of TDAA throughout the ocean indicates that it belongs to the recalcitrant or refractory pool of DOC; this pool is hardly removed in the deep sea and may only be degraded by photochemical reactions as it is returned into surface waters in the course of ocean circulation (Legendre et al., 2015). Our TDAA data reveal no depthdependent trend, but our data coverage is not sufficient to detect any spatial variation. The distribution of DOC is, however, well known with its maximum in surface water with $40-80 \mu \mathrm{mol} \mathrm{C} \mathrm{kg}^{-1}$ and depletion in deep water with DOC concentrations from $>50 \mu \mathrm{mol} \mathrm{C} \mathrm{kg}{ }^{-1}$ in the North Atlantic to $39 \mu \mathrm{mol} \mathrm{C} \mathrm{kg}{ }^{-1}$ in the North Pacific deep water (Carlson and Hansell, 2015; Hansell et al., 2009). Due to our limited number of measurements, we may have missed spatial variations which could elucidate TDAA sources and cycling processes in the ocean as is the case for DOC. Respiration of DOC may be an important removal process in shallower waters (Reinthaler et al., 2006) while a large proportion of the DOC reduction on its way to the Pacific on the deep conveyer belt could be related to adsorption to POC, partly via gel formation (Druffel and Williams, 1990).

TDAA may be among the constituents of DOC, which interact with SPM as both are transported with their specific water masses by the ocean conveyer belt. Interaction with SPM is suggested by the relative similarity in AA composition of TDAA and SPM. Moreover, SPM carries the second largest pool of POC and AA in the ocean, which has not been accounted for in carbon budgets and whose role in oceanic biogeochemical cycling has received little attention. The total abundance of POC, TN, and AA in SPM can be calculated using average concentrations (Table 1 ) in the ocean volume between $0-200 \mathrm{~m}$ and between $200 \mathrm{~m}$ and the sea floor (Costello et al., 2010). These calculations show that there is $443 \mathrm{Pg}$ of total suspended matter in the ocean of which or- 
ganic carbon comprises $48 \mathrm{Pg} \mathrm{C}$, amino acids $35 \mathrm{Pg} \mathrm{AA}$, and total nitrogen $6 \mathrm{Pg} \mathrm{N}$. The relative similarity of AA spectra in SPM and TDAA suggests interaction between the two pools at shallower depths and the build-up of an equilibrium, so that both pools remain constant in concentrations and composition with depths. Like DOC, which was suggested to be recalcitrant in the deep sea (Hansell and Carlson, 2013), SPM may only be affected by degradation and repackaging into aggregates as it is reintroduced into surface water by ocean circulation. Several studies, however, suggest that SPM may be an important food source for deep-living zooplankton (Koppelmann et al., 2009; Hannides et al., 2013; Gloeckler et al., 2018). If there are no removal processes in the deep ocean, we would expect SPM and their organic constituents to be exported from the Atlantic via the deep ocean circulation and to accumulate in the Pacific.

\section{Conclusions}

The PCA of a set of 1425 samples consisting of sinking particle, SPM, sediment, and water samples produced two factors which separate AA in sinking particles and sediments on the one hand from SPM and DOM on the other hand. As the PCA produced two branches diverging with water and sediment depth, strong interactions between the sinking and suspended particles pools can be excluded.

The relative degradation of sinking particles and sediments, dominated by Gly, Asp, Glu, and Ala, can be tracked by a new degradation indicator named sediment degradation index (SDI) derived from the first factor of the PCA and correlated with the often-used degradation index (DI). Except the SDI and the DI, the other biogeochemical indicators tested here (Asp / $\beta$-Ala, Glu / $\gamma$-Aba, RI) are not better than POC concentrations for a relative classification of organic matter degradation. The SDI is moreover capable of separating oxic and anoxic diagenetic conditions at an SDI between 0 and -0.2 (with values $<-0.2$ indicating oxic and values $>0$ indicating anoxic diagenetic conditions). Application of the SDI furthermore shows that the diagenetic signal from the water column is preserved in sediments deposited under anoxic conditions. The correlation of the SDI with POC shows that anoxic diagenesis enhances POC accumulation in sediments compared to oxic diagenesis.

A novel biogeochemical indicator derived from the second factor of the PCA named residence time indicator (RTI) depicts the transformation of SPM enriched in plankton-derived AA in the epipelagic ocean to a constant composition in the meso- and bathypelagic ocean. The deep SPM is probably the residue of microbial processing and is not utilizable by enzymes under the present oceanic conditions. This constant composition of SPM is corroborated by a constant $\delta^{15} \mathrm{~N}$ value below $200 \mathrm{~m}$ irrespective of the area of study.

DOM has almost constant AA composition throughout the water column as well as in pore water, dominated by Ser, Gly,
His, Ala, and Orn, pursuing the same accumulation AA pathway as found in deep SPM. Comparison with literature data shows that the amount of AA released depends on the intensity of hydrolysis and that about $50 \%$ of the amide linkages detectable by NMR spectroscopy cannot be hydrolyzed. Similar to SPM the proteins are not utilizable by microorganisms. Protein-like dissolved material was determined to be on average 2670 years old (Loh et al., 2004), showing that these refractory molecules are cycled several times before they can be removed by as of yet unknown processes.

Based on our AA data we have calculated the total oceanic AA inventory and found that TDAAs are the largest oceanic AA pool with a total amount of $200 \pm 70 \mathrm{Pg} \mathrm{AA}$, and AAs comprise $14 \%$ of the oceanic DOC and $45 \%$ of oceanic DON.

The pool transported with SPM is 35 Pg AA. SPM, furthermore, carries $48 \mathrm{Pg} \mathrm{C}$ and $6 \mathrm{Pg} \mathrm{N}$ not accounted for in global carbon and nitrogen budgets. At present it is not known how the oceanic DOM and SPM particulate organic matter pool is formed and how this rather recalcitrant organic matter can be removed from its ambient water mass. It is feasible that these organic matter pools have fluctuated in the past due to change in oceanic physicochemical conditions (Ridgwell and Arndt, 2015). It is intriguing to understand how the accumulation or reduction of these carbon and nitrogen pools has interacted with climate and environmental changes in the geological history, but it is vital to understand the response to ongoing and future climate change.

Data availability. Excerpts of the data were used in previous publications (i) from the Kara Sea in Gaye et al. (2007), Nagel et al. (2005), and Unger et al. (2009); (ii) from the northern Indian Ocean in Gaye et al. (2013), Gaye-Haake et al. (2005), Möbius et al. (2011), and Suthhof et al. (2001); (iii) from the Mediterranean Sea in Möbius (2013) and Möbius et al. (2010); (iv) from the Namibian upwelling in Nagel et al. (2016); and (v) from the Pacific in Paul et al. (2018). The entire set of amino acid data was submitted to PANGAEA and data are available at https://doi.org/10.1594/PANGAEA.940723 (Gaye et al., 2022a) and https://doi.org/10.1594/PANGAEA.940791 (Gaye et al., 2022b). Data from the Pacific are available at https://doi.org/10.1594/PANGAEA.885391 (Paul et al., 2017c), https://doi.org/10.1594/PANGAEA.881804 (Paul et al., 2017a), and https://doi.org/10.1594/PANGAEA.881813 (Paul et al., 2017b) and for TOC at https://doi.org/10.1594/PANGAEA.884975 (Haeckel, 2018a), https://doi.org/10.1594/PANGAEA.885023 (Haeckel, 2018c), and https://doi.org/10.1594/PANGAEA.884981 (Haeckel, 2018b).

Supplement. The supplement related to this article is available online at: https://doi.org/10.5194/bg-19-807-2022-supplement. 
Author contributions. BG, NL, TR, and KCE designed the study and led the projects in which samples were taken and analyzed. NL developed and refined the AA analyses. NL, NH, and SALP contributed and analyzed samples from the southern Indian Ocean and the Pacific. BG wrote the manuscript with contributions of all coauthors.

Competing interests. The contact author has declared that neither they nor their co-authors have any competing interests.

Disclaimer. Publisher's note: Copernicus Publications remains neutral with regard to jurisdictional claims in published maps and institutional affiliations.

Acknowledgements. This work is based on samples taken during cruises of the research vessels Sonne, Meteor, Maria S. Merian, Pelagia, Orv Sagar Kanya, and Akademik Petrov. We are grateful to all officers and crew of these research vessels. We are indebted to Venugopalan Ittekkot, who initiated and inspired this work and led many of the research projects. We thank Desmond Gracias, Areef Sardar, and Fernando Vijayan from NIO, Goa, India, for technical support on board. We thank Inken Preuss, Annika Moje, Tim Jesper Suhrhoff, and Seinab Bohsung for help with pore water sampling during the cruises SO239 and SO242. We are indebted to Frauke Langenberg and Marc Metzke for their high-quality analyses and to Dilek Topcu for help with compiling and archiving the large data sets. We are very thankful to Cindy Lee and the two anonymous reviewers for their critical comments on the paper.

Financial support. This research has been supported by the German Federal Ministry of Education and Research (grant no. 03F0707G) in the framework of JPI Oceans EcoMining-DEU Ecological Aspects of Deep-Sea Mining to Jacobs University Bremen. Sampling in the southern Indian Ocean was conducted within the framework of the INDEX program of the Federal Institute of Geosciences and Natural Resources (BGR). The DFG and BMBF financed the finalized projects in the northern Indian Ocean and Atlantic (Indian-German Program, JGOFS, BIGSET), the Mediterranean Sea (MEDNIT), the Namibian upwelling (GENUS), and the Kara Sea (SIRRO).

Review statement. This paper was edited by Yuan Shen and reviewed by two anonymous referees.

\section{References}

Abramson, L., Lee, C., Liu, Z., Wakeham, S. G., and Szlosek, J.: Exchange between suspended and sinking particles in the northwest Mediterranean as inferred from the organic composition of in situ pump and sediment trap samples, Limnol. Oceanogr., 55, 725-739, 2011.
Alldredge, A.: The carbon, nitrogen and mass content of marine snow as a function of aggregate size, Deep-Sea Res. Pt. I, 45, 529-541, 1998.

Alldredge, A. L. and Silver, M. W.: Charateristics, dynamics and significance of marine snow, Prog. Oceanogr., 20, 41-82, 1988.

Altabet, M. A.: Isotopic Tracers of the Marine Nitrogen Cycle: Present and Past, in: Marine Organic Matter: Biomarkers, Isotopes and DNA, The Handbook of Environmental Chemistry, edited by: Volkman, J. K., Springer, Berlin, Heidelberg, 251293, https://doi.org/10.1007/698_2_008, 2006.

Altabet, M. A., Deuser, W. G., Honjo, S., and Stienen, C.: Seasonal and depth-related changes in the source of sinking particles in the North Atlantic, Nature, 354, 136-139, 1991.

Aluwihare, L. I., Repeta, D. J., Pantoja, S., and Johnson, C. G.: Two chemically distinct pools of organic nitrogen accumulate in the ocean, Science, 308, 1007-1010, 2005.

Aristegui, J., Gasol, J. M., Duarte, C. M., and Herndl, G. J.: Microbial oceanography of the dark ocean's pelagic realm, Limnol. Oceanogr., 54, 1501-1529, https://doi.org/10.4319/lo.2009.54.5.1501, 2009.

Armstrong, R. A., Lee, C., Hedges, J. I., Honjo, S., and Wakeham, S. G.: A new, mechanistic model for organic carbon fluxes in the ocean based on the quantitative association of POC with ballast minerals, Deep-Sea Res. Pt. II, 49, 219-236, 2002.

Arnarson, T. S. and Keil, R. G.: Influence of organic-mineral aggregates on microbial degradation of the dinoflagellate Scrippsiella trochoidea, Geochim. Cosmochim. Ac., 69, 2111-2117, https://doi.org/10.1016/j.gca.2004.11.004, 2005.

Arnarson, T. S. and Keil, R. G.: Changes in organic mattermineral interactions for marine sediments with varying oxygen exposure times, Geochim. Cosmochim. Ac., 71, 3545-3556, https://doi.org/10.1016/j.gca.2007.04.027, 2007.

Arrieta, J. M., Mayol, E., Hansman, R. L., Herndl, G. J., Dittmar, T., and Duarte, C. M.: Dilution limits dissolved organic carbon utilization in the deep ocean, Science, 348, 331-333, https://doi.org/10.1126/science.1258955, 2015.

Benner, R. and Kaiser, J.: Abundance of amino sugars and peptidoglycan in marine particulate and dissolved organic matter, Limnol. Oceanogr., 48, 118-128, 2003.

Benner, R., Louchouarn, P., and Amon, R. M. W.: Terrigenous dissolved organic matter in the Arctic Ocean and its transport to surface and deep waters of the North Atlantic, Global Biogeochem. Cy., 19, GB2025, https://doi.org/10.1029/2004GB002398, 2005.

Boetius, A. and Lochte, K.: Regulation of microbial enzymatic degradation of organic matter in deep-sea sediments, Mar. Ecol.Prog. Ser., 104, 299-307, https://doi.org/10.3354/meps104299, 1994.

Boetius, A., Ferdelman, T., and Lochte, K.: Bacterial activity in sediments of the deep Arabian Sea in relation to vertical flux, DeepSea Res. Pt. II, 47, 2835-2875, https://doi.org/10.1016/s09670645(00)00051-5, 2000a.

Boetius, A., Springer, B., and Petry, C.: Microbial activity and particulate matter in the benthic nepheloid layer (BNL) of the deep Arabian Sea, Deep-Sea Res. Pt. II, 47, 2687-2706, https://doi.org/10.1016/s0967-0645(00)00045-x, 2000b.

Boyd, P., Claustre, H., Levy, M., Siegel, D., and Weber, T.: Multi-faceted particle pumps drive carbon sequestration in the ocean, Nature, 568, 327-335, https://doi.org/10.1038/s41586019-1098-2, 2019. 
Boyd, S. R.: Nitrogen in future biosphere studies, Chem. Geol., 176, 1-30, https://doi.org/10.1016/S0009-2541(00)00405-8, 2001.

Brockmeyer, B. and Spitzy, A.: Evaluation of a Disc Tube Methodology for Nano- and Ultrafiltration of Natural Dissolved Organic Matter, Int. J. Org. Chem., 3, 17-25, 2013.

Bronk, D. A.: Chapter 5 - Dynamics of DON, in: Biogeochemistry of Marine Dissolved Organic Matter, edited by: Hansell, D. A., and Carlson, C. A., Academic Press, San Diego, 153-247, https://doi.org/10.1016/B978-012323841-2/50007-5, 2002.

Carlson, C. A. and Hansell, D. A.: Chapter 3 - DOM Sources, Sinks, Reactivity, and Budgets, in: Biogeochemistry of Marine Dissolved Organic Matter, 2nd Edn., edited by: Hansell, D. A. and Carlson, C. A., Academic Press, Boston, 65-126, https://doi.org/10.1016/B978-0-12-405940-5.00003-0, 2015.

Carr, S. A., Mills, C. T., and Mandernack, K. W.: The use of amino acid indices for assessing organic matter quality and microbial abundance in deep-sea Antarctic sediments of IODP Expedition 318, Mar. Chem., 186, 72-82, https://doi.org/10.1016/j.marchem.2016.08.002, 2016.

Cho, B. C. and Azam, F.: Major role of bacteria in biogeochemical fluxes in the ocean's interior, Nature, 332, 441-443, 1988.

Ciais, P., Sabine, C., Bala, G., Bopp, L., Brovkin, V., Canadell, J., Chhabra, A., DeFries, R., Galloway, J., Heimann, M., Jones, C., Le Quere, C., Myneni, R. B., Piao, S. L., Thornton, P., Ahlstrom, A., Anav, A., Andrews, O., Archer, D., Arora, V., Bonan, G., Borges, A. V., Bousquet, P., Bouwman, L., Bruhwiler, L. M., Caldeira, K., Cao, L., Chappellaz, J., Chevallier, F., Cleveland, C., Cox, P., Dentener, F. J., Doney, S. C., Erisman, J. W., Euskirchen, E. S., Friedlingstein, P., Gruber, N., Gurney, K., Holland, E. A., Hopwood, B., Houghton, R. A., House, J. I., Houweling, S., Hunter, S., Hurtt, G., Jacobson, A. D., Jain, A., Joos, F., Jungclaus, J., Kaplan, J. O., Kato, E., Keeling, R., Khatiwala, S., Kirschke, S., Goldewijk, K. K., Kloster, S., Koven, C., Kroeze, C., Lamarque, J. F., Lassey, K., Law, R. M., Lenton, A., Lomas, M. R., Luo, Y. Q., Maki, T., Marland, G., Matthews, H. D., Mayorga, E., Melton, J. R., Metzl, N., Munhoven, G., Niwa, Y., Norby, R. J., O’Connor, F., Orr, J., Park, G. H., Patra, P., Peregon, A., Peters, W., Peylin, P., Piper, S., Pongratz, J., Poulter, B., Raymond, P. A., Rayner, P., Ridgwell, A., Ringeval, B., Rodenbeck, C., Saunois, M., Schmittner, A., Schuur, E., Sitch, S., Spahni, R., Stocker, B., Takahashi, T., Thompson, R. L., Tjiputra, J., van der Werf, G., van Vuuren, D., Voulgarakis, A., Wania, R., Zaehle, S., and Zeng, N.: Carbon and Other Biogeochemical Cycles, Climate Change 2013: The Physical Science Basis, Cambridge Univ. Press, Cambridge, 465-570, ISBN 978-1-10766182, 978-1-107-05799-9, 2014.

Cohen, J.: Statistical power analysis for the behavorial sciences, 2nd Edn., L. Erlbaum Associates, edited by: Hillsdale, N. J., 567 pp., ISBN 978-0805802832, 1988.

Costello, M. J., Cheung, A., and De Hauwere, N.: Surface Area and the Seabed Area, Volume, Depth, Slope, and Topographic Variation for the World's Seas, Oceans, and Countries, Environ. Sci. Technol., 44, 8821-8828, https://doi.org/10.1021/es1012752, 2010.

Cowie, G. L. and Hedges, J. I.: Sources and reactivities of amino acids in a coastal marine environment, Limnol. Oceanogr., 37, 703-724, 1992.
Cowie, G. L. and Hedges, J. I.: Biogeochemical indicators of diagenetic alteration in natural organic-matter mixtures, Nature, 369, 304-307, 1994.

Cowie, G. L., Hedges, J. I., Prahl, F. G., and De Lange, G. J.: Elemental and major biochemical changes across an oxidation front in a relict turbidite: An oxygen effect, Geochim. Cosmochim. Ac., 59, 33-46, 1995.

Dauwe, B. and Middelburg, J. J.: Amino acids and hexosamines as indicators of organic matter degradation state in North Sea sediments, Limnol. Oceanogr., 43, 782-798, 1998.

Dauwe, B., Middelburg, J. J., Hermann, P. M. J., and Heip, C. H. R.: Linking diagenetic alteration of amino acids and bulk organic matter reactivity, Limnol. Oceanogr., 44, 1809-1814, 1999.

Davis, J. and Benner, R.: Seasonal trends in the abundance, composition and bioavailability of particulate and dissolved organic matter in the Chukchi/Beaufort Seas and western Canada Basin, Deep-Sea Res. Pt. II, 52, 3396-3410, https://doi.org/10.1016/j.dsr2.2005.09.006, 2005.

Davis, J., Kaiser, K., and Benner, R.: Amino acid and amino sugar yields and compositions as indicators of dissolved organic matter diagenesis, Org. Geochem., 40, 343-352, https://doi.org/10.1016/j.orggeochem.2008.12.003, 2009.

Degens, E. T. and Ittekkot, V.: Dissolved organic carbon - An overview, Mitt. Geol.-Paläont. Inst. Univ. Hamburg, Heft 55, $21-$ 38, 1983.

Degens, E. T. and Ittekkot, V.: A new look at clay-organic interactions, in: Ein Nord-Süd Profil: Zentraleuropa-MittelmmeerraumAfrika, edited by: Degens, E. T., Krumbein, W. E., and Prashnowsky, A. A., Mitteilungen aus dem GeologischPaläontologischen Institut der Universität Hamburg, KrauseDruck, Stade, 229-248, 1984.

Degens, E. T. and Ittekkot, V.: Particulate organic carbon - An overview, Mitt. Geol.-Paläont. Inst. Univ. Hamburg, SCOPE/UNEP Sonderband, Heft 58, 7-27, 1985.

Degens, E. T. and Mopper, K.: Early diagenesis of organic matter in marine soils, Soil Sci., 119, 65-72, https://doi.org/10.1097/00010694-197501000-00010, 1975.

Druffel, E. R. M. and Williams, P. M.: Identification of a deep marine source of particulate organic carbon using bomb ${ }^{14} \mathrm{C}, \mathrm{Na}-$ ture, 347, 172-174, https://doi.org/10.1038/347172a0, 1990.

Emeis, K.-C., Mara, P., Schlarbaum, T., Möbius, J., Dähnke, K., Struck, U., Mihalopoulos, N., and Krom, M.: External inputs and internal $\mathrm{N}$ cycling traced by isotope ratios of nitrate, dissolved reduced nitrogen, and particulate nitrogen in the eastern Mediterranean Sea, J. Geophys. Res., 115, G04041, https://doi.org/10.1029/2009JG001214, 2010.

England, M. E.: The Age of Water and Ventilation Timescales in a Global Ocean Model, J. Phys. Oceanogr., 25, 2756-2777, https://doi.org/10.1175/15200485(1995)025<2756:taowav>2.0.co;2, 1995.

Fowler, S. W. and Knauer, G. A.: Role of large particles in the transport of elements and organic compounds through the oceanic water column, Prog. Oceanogr., 16, 147-194, https://doi.org/10.1016/0079-6611(86)90032-7, 1986.

Galbraith, E. D., Kienast, M., Albuquerque, A. L., Altabet, M. A., Batista, F., Bianchi, D., Calvert, S. E., Contreras, S., Crosta, X., De Pol-Holz, R., Dubois, N., Etourneau, J., Francois, R., Hsu, T. C., Ivanochko, T., Jaccard, S. L., Kao, S. J., Kiefer, T., Kienast, S., Lehmann, M. F., Martinez, P., McCarthy, M., Meck- 
ler, A. N., Mix, A., Mobius, J., Pedersen, T. F., Pichevin, L., Quan, T. M., Robinson, R. S., Ryabenko, E., Schmittner, A., Schneider, R., Schneider-Mor, A., Shigemitsu, M., Sinclair, D., Somes, C., Studer, A. S., Tesdal, J. E., Thunell, R., Yang, J. Y. T., and Members, N. W. G.: The acceleration of oceanic denitrification during deglacial warming, Nat. Geosci., 6, 579-584, https://doi.org/10.1038/ngeo1832, 2013.

Gaye-Haake, B., Unger, D., Nöthig, E.-M., Okolodkov, Y., Fahl, K., and Ittekkot, V.: Particle fluxes from short term sediment trap deployments in late summer in the southern Kara Sea, in: Siberian River Run-off in the Kara Sea: Characterisation, Quantification, Variability, and Environmental Significance, edited by: Stein, R., Fahl, K., Fütterer, D. K., Galimov, E., and Stepanets, O., Proceedings in Marine Science, Elsevier, Amsterdam, 309328, 2003.

Gaye-Haake, B., Lahajnar, N., Emeis, K.-C., Unger, D., Rixen, T., Suthhof, A., Ramaswamy, V., Schulz, H., Paropkari, A. L., Guptha, M. V. S., and Ittekkot, V.: Stable nitrogen isotopic ratios of sinking particles and sediments from the northern Indian Ocean, Mar. Chem., 96, 243-255, 2005.

Gaye, B., Fahl, K., Kodina, L. A., Lahajnar, N., Nagel, B., Unger, D., and Gebhardt, A. C.: Particulate matter fluxes in the southern and central Kara Sea compared to sediments: Bulk fluxes, amino acids, stable carbon and nitrogen isotopes, sterols and fatty acids, Cont. Shelf Res., 27, 2570-2594, https://doi.org/10.1016/j.csr.2007.07.003, 2007.

Gaye, B., Wiesner, M. G., and Lahajnar, N.: Nitrogen sources in the South China Sea, as discerned from stable nitrogen isotopic ratios in rivers, sinking particles, and sediments, Mar. Chem., 114, 72-85, 2009.

Gaye, B., Nagel, B., Daehnke, K., Rixen, T., and Emeis, K.C.: Evidence of parallel denitrification and nitrite oxidation in the ODZ of the Arabian Sea from paired stable isotopes of nitrate and nitrite, Global Biogeochem. Cy., 27, 1059-1071, https://doi.org/10.1002/2011GB004115, 2013a.

Gaye, B., Nagel, B., Dähnke, K., Rixen, T., Lahajnar, N., and Emeis, K.-C.: Amino acid composition and $\delta^{15} \mathrm{~N}$ of suspended matter in the Arabian Sea: implications for organic matter sources and degradation, Biogeosciences, 10, 7689-7702, https://doi.org/10.5194/bg-10-7689-2013, 2013b.

Gaye, B., Boell, A., Segschneider, J., Burdanowitz, N., Emeis, K.-C., Ramaswamy, V., Lahajnar, N., Lueckge, A., and Rixen, T.: Glacial-interglacial changes and Holocene variations in Arabian Sea denitrification, Biogeosciences, 15, 507-527, https://doi.org/10.5194/bg-15-507-2018, 2018.

Gaye, B., Lahajnar, N., Harms, N., Paul, S. A. L., Rixen, T., and Emeis, K.-C.: Amino acids and hexosamines in suspended matter samples collected in different oceanic areas between 1999 and 2017 from shelf seas to the deep ocean, PANGAEA [data set], https://doi.org/10.1594/PANGAEA.940723, 2022a.

Gaye, B., Lahajnar, N., Harms, N., Paul, S. A. L., Rixen, T., and Emeis, K.-C.: Amino acids and hexosamines of sediment samples from different oceanic areas between 1987 and 2015 from shelf seas to the deep ocean, PANGAEA [data set], https://doi.org/10.1594/PANGAEA.940791, 2022b.

Gebbie, G. and Huybers, P.: The Mean Age of Ocean Waters Inferred from Radiocarbon Observations: Sensitivity to Surface Sources and Accounting for Mixing Histories, J. Phys.
Oceanogr., 42, 291-305, https://doi.org/10.1175/jpo-d-11-043.1, 2012.

Gloeckler, K., Choy, C. A., Hannides, C. C. S., Close, H. G., Goetze, E., Popp, B. N., and Drazen, J. C.: Stable isotope analysis of micronekton around Hawaii reveals suspended particles are an important nutritional source in the lower mesopelagic and upper bathypelagic zones, Limnol. Oceanogr., 63, 1168-1180, https://doi.org/10.1002/lno.10762, 2018.

Goutx, M., Wakeham, S. G., Lee, C., Duflos, M., Guigue, C., Liu, Z., Moriceau, B., Sempére, R., Tedetti, M., and Xue, J.: Composition and degradation of marine particles with different settling velocities in the northwestern Mediterranean Sea, Limnol. Oceanogr., 52, 1645-1664, 2007.

Gruber, N.: The marine nitrogen cycle: Overview and challenges, in: Nitrogen in the Marine Environment, 2nd Edn., edited by: Capone, D. G., Bronk, D. A., Mulholland, M. R., and Carpenter, E., Academic Press, San Diego, 51, ISBN 9780123725226, 2008.

Guo, J., Liang, S.-K., Li, X.-J., Li, W., Wang, Y., and Su, R.-G.: Composition and bioavailability of dissolved organic matter in different water masses of the East China Sea, Estuar. Coas. Shelf Sci., 212, 189-202, https://doi.org/10.1016/j.ecss.2018.07.009, 2018.

Haake, B., Rixen, T., and Ittekkot, V.: Variability of monsoonal upwelling signals in the deep western Arabian Sea, Mitt. Geol.Paläont. Inst. Univ. Hamburg, Scope/UNEP Sonderband, Heft 76, 85-96, 1993a.

Haake, B., Ittekkot, V., Honjo, S., and Manganini, S.: Amino acids, hexosamines and carbohydrate fluxes to the deep Subarctic Pacific (Station P), Deep-Sea Res. Pt. I, 40, 547-560, 1993b.

Haake, B., Ittekkot, V., Ramaswamy, V., Nair, R. R., and Honjo, S.: Fluxes of amino acids and hexosamines of the deep Arabian Sea, Mar. Chem., 40, 291-314, 1992.

Haake, B., Rixen, T., Reemtsma, T., Ramaswamy, V., and Ittekkot, V.: Processes determining seasonality and interannual variability of settling particle fluxes to the deep Arabian Sea, in: Particle Flux in the Ocean, edited by: Ittekkot, V., Schäfer, P., Honjo, S., and Depetris, P. J., John Wiley\&Sons Ltd., 251-270, ISBN 0471-96073-X, 1996.

Haeckel, M.: Particulate geochemistry of sediment core SO242/1_108-1_MUC 26, PANGAEA [data set], https://doi.org/10.1594/PANGAEA.884975, 2018a.

Haeckel, M.: Particulate geochemistry of sediment core SO242/1_38-1_GC 1, PANGAEA [data set], https://doi.org/10.1594/PANGAEA.884981, 2018b.

Haeckel, M.: Particulate geochemistry of sediment push core SO242/2_166_PUC-70, PANGAEA [data set], https://doi.org/10.1594/PANGAEA.885023, $2018 \mathrm{c}$.

Hannides, C. C. S., Popp, B. N., Choy, C. A., and Drazen, J. C.: Midwater zooplankton and suspended particle dynamics in the North Pacific Subtropical Gyre: A stable isotope perspective, Limnol. Oceanogr., 58, 1931-1946, https://doi.org/10.4319/lo.2013.58.6.1931, 2013.

Hansell, D. A. and Carlson, C. A.: Localized refractory dissolved organic carbon sinks in the deep ocean, Global Biogeochem. Cy., 27, 705-710, 2013.

Hansell, D., Carlson, C. A., Repeta, D. J., and Schlitzer, R.: Dissolved organic matter in the ocean, Oceanography, 22, 202-211, 2009. 
Harms, N. C., Lahajnar, N., Gaye, B., Rixen, T., Dähnke, K., Ankele, M., Schwarz-Schampera, U., and Emeis, K. C.: Nutrient distribution and nitrogen and oxygen isotopic composition of nitrate in water masses of the subtropical southern Indian Ocean, Biogeosciences, 16, 2715-2732, https://doi.org/10.5194/bg-162715-2019, 2019.

Harms, N. C., Lahajnar, N., Gaye, B., Rixen, T., SchwarzSchampera, U., and Emeis, K.-C.: Sediment trap-derived particulate matter fluxes in the oligotrophic subtropical gyre of the South Indian Ocean, Deep-Sea Res. Pt. II, 183, 104924, https://doi.org/10.1016/j.dsr2.2020.104924, 2021.

Hedges, J. I. and Hare, P. E.: Amino acid adsorption by clay minerals in distilled water, Geochim. Cosmochim. Ac., 51, 255-259, 1987.

Hedges, J. I. and Keil, R. G.: Sedimentary organic matter preservation an assessment and speculative synthesis, Mar. Chem., 49, 137-139, https://doi.org/10.1016/0304-4203(95)00013-h, 1995.

Hildebrandt, Tatjana M., Nunes Nesi, A., Araújo, Wagner L., and Braun, H.-P.: Amino Acid Catabolism in Plants, Mol. Plant, 8, 1563-1579, https://doi.org/10.1016/j.molp.2015.09.005, 2015.

Honjo, S., Manganini, S. J., Krishfield, R. A., and Francois, R.: Particulate organic carbon fluxes to the ocean interior and factors controlling the biological pump: A synthesis of global sediment trap programs since 1983, Prog. Oceanogr., 76, 217-285, https://doi.org/10.1016/j.pocean.2007.11.003, 2008.

Ingalls, A. E., Aller, R. C., Lee, C., and Wakeham, S. G.: Organic matter diagenesis in shallow water carbonate sediments, Geochim. Cosmochim. Ac., 68, 4263-4379, 2004.

Ingalls, A. E., Liu, Z., and Lee, C.: Seasonal trends in the pigment and amino acid compositions of sinking particles in biogenic $\mathrm{CaCO}_{3}$ and $\mathrm{SiO}_{2}$ dominated regions of the Pacific sector of the Southern Ocean along $170^{\circ} \mathrm{W}$, Deep-Sea Res. Pt. I, 53, 836-859, 2006.

Ittekkot, V.: Verteilung von gelöstem organischen Kohlenstoff, gelösten Zuckern und Aminosäuren in Fladengrund, nördliche Nordsee (FLEX 1976), Mitt. Geol.-Paläont. Inst. Univ. Hamburg, Heft 51, 115-187, 1981.

Ittekkot, V. and Arain, R.: Nature of Particulate Organic-Matter in the River Indus, Pakistan, Geochim. Cosmochim. Ac., 50, 1643 1653, https://doi.org/10.1016/0016-7037(86)90127-4, 1986.

Ittekkot, V., Degens, E. T., and Honjo, S.: Seasonality in the fluxes of sugars, amino acids, and amino sugars to the deep ocean: Panama Basin, Deep-Sea Res., 31, 1071-1083, 1984a.

Ittekkot, V., Deuser, W. G., and Degens, E. T.: Seasonality in the fluxes of sugars, amino acids, and amino sugars to the deep ocean: Sargasso Sea, Deep-Sea Res., 31, 1057-1069, 1984b.

Ittekkot, V., Safiullah, S., and Arain, R.: Nature of OrganicMatter in Rivers with Deep-Sea Connections - the GangesBrahmaputra and Indus, Sci. Total Environ., 58, 93-107, https://doi.org/10.1016/0048-9697(86)90080-x, 1986.

Jennerjahn, T. and Ittekkot, V.: Organic matter in sediments in the mangrove areas and adjacent continental margins of Brazil: I. Amino acids and hexosamines, Oceanol. Acta, 20, 359-369, 1997.

Kaiser, K. and Benner, R.: Biochemical composition and size distribution of organic matter at the Pacific and Atlantic time-series stations, Mar. Chem., 113, 63-77, https://doi.org/10.1016/j.marchem.2008.12.004, 2009.
Kandler, O.: Cell-wall structures in methane bacteria - evolution of procaryotes, Naturwissenschaften, 66, 95-105, https://doi.org/10.1007/bf00373500, 1979.

Karl, D., Knauer, G. A., and Martin, A. P.: Downward flux of particulate organic matter in the ocean: a particle composition paradox, Nature, 332, 438-441, 1988.

Keil, R. G. and Kirchman, D. L.: Dissolved Combined Amino Acids: Chemical Form and Utilization by Marine Bacteria, Limnol. Oceanogr., 38, 1256-1270, 1993.

Keil, R. G. and Kirchman, D. L.: Abiotic Transformation of Labile Protein to Refractory Protein in Sea-Water, Mar. Chem., 45, 187196, https://doi.org/10.1016/0304-4203(94)90002-7, 1994.

Keil, R. G. and Kirchman, D. L.: Utilization of dissolved protein and amino acids in the northern Sargasso Sea, Aquat. Microb. Ecol., 18, 293-300, 1999.

Keil, R. G., Montlucon, D. B., Prahl, F. G., and Hedges, J. I.: Sorptive Preservation of Labile Organic-Matter in Marine-Sediments, Nature, 370, 549-552, https://doi.org/10.1038/370549a0, 1994.

Kienast, M., Lehmann, M. F., Timmermann, A., Galbraith, E., Bolliet, T., Holboum, A., Normandeau, C., and Laj, C.: A mid-Holocene transition in the nitrogen dynamics of the western equatorial Pacific: Evidence of a deepening thermocline?, Geophys. Res. Lett., 35, L23610, https://doi.org/10.1029/2008gl035464, 2008.

Kim, T. H., Kim, G., Shen, Y., and Benner, R.: Strong linkages between surface and deep-water dissolved organic matter in the East/Japan Sea, Biogeosciences, 14, 2561-2570, https://doi.org/10.5194/bg-14-2561-2017, 2017.

King, K. J.: Amino acid composition of the silicified matrix in fossil polycystine Radiolaria, Micropaleontology, 21, 215-226, 1975.

King, K. J. and Hare, P. E.: Amino acid composition of the test as a taxonomic character for living and fossil planktonic foraminifera, Micropaleontology, 18, 285-293, 1972.

Klein, I., von Rad, U., and Durner, J.: Homoserine lactones: do plants really listen to bacterial talk?, Plant Signal. Behav., 4, 50 $51,2009$.

Koppelmann, R., Bottger-Schnack, R., Mobius, J., and Weikert, H.: Trophic relationships of zooplankton in the eastern Mediterranean based on stable isotope measurements, J. Plankton Res., 31, 669-686, https://doi.org/10.1093/plankt/fbp013, 2009.

Lahajnar, N., Rixen, T., Gaye-Haake, B., Schafer, P., and Ittekkot, V.: Dissolved organic carbon (DOC) fluxes of deep-sea sediments from the Arabian Sea and NE Atlantic, Deep-Sea Res. Pt. II, 52, 1947-1964, https://doi.org/10.1016/j.dsr2.2005.05.006, 2005.

Lahajnar, N., Wiesner, M. G., and Gaye, B.: Fluxes of amino acids and hexosamines to the deep South China Sea, Deep-Sea Res. Pt. I, 54, 2120-2144, https://doi.org/10.1016/j.dsr.2007.08.009, 2007.

Lam, P. J. and Marchal, O.: Insights into Particle Cycling from Thorium and Particle Data, in: Annual Review of Marine Science, Vol 7, edited by: Carlson, C. A. and Giovannoni, S. J., Annual Review of Marine Science, Annual Reviews, Palo Alto, 159-184, https://doi.org/10.1146/annurev-marine-010814-015623, 2015.

Lee, C.: Amino acids and amine biogeochemistry in marine particulate material and sediments, in: Nitrogen cycling in coastal marine environments, edited by: Blackburn, T. H., and Sörensen, J., SCOPE, Wiley and Sons, 125-141, ISBN 047191404 5, 1988. 
Lee, C. and Cronin, C.: The vertical flux of particulate organic nitrogen in the sea: decomposition of amino acids in the Peru upwelling area and the equatorial Atlantic, J. Mar. Res., 40, 227$251,1982$.

Lee, C. and Cronin, C.: Particulate amino acids in the sea: Effects of primary productivity and biological decomposition, J. Mar. Res., 42, 1075-1097, 1984.

Lee, C., Wakeham, S., and Arnosti, C.: Particulate organic matter in the sea: The composition conundrum, Ambio, 33, 565-575, https://doi.org/10.1639/00447447(2004)033[0565:pomits]2.0.co;2, 2004.

Legendre, L., Rivkin, R. B., Weinbauer, M. G., Guidi, L., and Uitz, J.: The microbial carbon pump concept: Potential biogeochemical significance in the globally changing ocean, Prog. Oceanogr., 134, 432-450, https://doi.org/10.1016/j.pocean.2015.01.008, 2015.

Loh, A. N., Bauer, J. E., and Druffel, E. R. M.: Variable ageing and storage of dissolved organic components in the open ocean, Nature, 430, 877-881, https://doi.org/10.1038/nature02780, 2004.

Loick-Wilde, N., Weber, S. C., Eglite, E., Liskow, I., Schulz-Bull, D., Wasmund, N., Wodarg, D., and Montoya, J. P.: De novo amino acid synthesis and turnover during N-2 fixation, Limnol. Oceanogr., 63, 1076-1092, https://doi.org/10.1002/lno.10755, 2018.

Lonborg, C., Alvarez-Salgado, X. A., Letscher, R. T., and Hansell, D. A.: Large Stimulation of Recalcitrant Dissolved Organic Carbon Degradation by Increasing Ocean Temperatures, Front. Mar. Sci., 4, 436, https://doi.org/10.3389/fmars.2017.00436, 2018.

Martin, J. H., Knauer, G. A., Karl, D. M., and Broenkow, W. W.: Vertex: carbon cycling in the northeast Pacific, Deep-Sea Res., 34, 267-285, 1987.

Mayzaud, P. and Martin, J. L. M.: Some aspects of biochemical and mineral composition of marine plankton J. Exp. Mar. Biol. Ecol., 17, 297-310, https://doi.org/10.1016/00220981(75)90005-2, 1975.

McCarthy, M., Pratum, T., Hedges, J., and Benner, R.: Chemical composition of dissolved organic nitrogen in the ocean, Nature, 390, 150-154, https://doi.org/10.1038/36535, 1997.

McCarthy, M. D., Benner, R., Lee, C., Hedges, J. I., and Fogel, M. L.: Amino acid carbon isotopic fractionation patterns in oceanic dissolved organic matter: an unaltered photoautotrophic source for dissolved organic nitrogen in the ocean?, Mar. Chem., 92, 123-134, 2004.

McCarthy, M. D., Benner, R., Lee, C., and Fogel, M. L.: Amino acid nitrogen isotopic fractionation patterns as indicators of heterotrophy in plankton, particulate, and dissolved organic matter, Geochim. Cosmochim. Ac., 71, 4727-4744, https://doi.org/10.1016/j.gca.2007.06.061, 2007.

McCave, I. N.: Size spectra and aggregation of suspended particles in the ocean, Deep-Sea Res., 31, 329-352, 1984.

Menzel, P., Anupama, K., Basavaiah, N., Das, B. K., Gaye, B., Herrmann, N., and Prasad, S.: The use of amino acid analyses in (palaeo-) limnological investigations: A comparative study of four Indian lakes in different climate regimes, Geochim. Cosmochim. Ac., 160, 25-37, https://doi.org/10.1016/j.gca.2015.03.028, 2015.

Menzel, P., Gaye, B., Wiesner, M. G., Prasad, S., Stebich, M., Das, B. K., Anoop, A., Riedel, N., and Basavaiah, N.: Influence of bottom water anoxia on nitrogen isotopic ratios and amino acid con- tributions of recent sediments from small eutrophic Lonar Lake, Central India, Limnol. Oceanogr., 58, 1061-1074, 2013.

Möbius, J.: Isotope fractionation during nitrogen remineralization (ammonification): Implications for nitrogen isotope biogeochemistry, Geochim. Cosmochim. Ac., 105, 422-432, 2013.

Möbius, J., Lahajnar, N., and Emeis, K.-C.: Diagenetic control on nitrogen isotope ratios in Holocene sapropels and recent sediments from the Eastern Mediterranean Sea, Biogeosciences 7, 3901-3914, https://doi.org/10.5194/bg-7-3901-2010, 2010.

Möbius, J., Gaye, B., Lahajnar, N., Bahlmann, E., and Emeis, K.C.: Influence of diagenesis on sedimentary $\ddot{a}^{15} \mathrm{~N}$ in the Arabian Sea over the last 130 kyr, Mar. Geol., 284, 127-138, 2011.

Müller, P. J.: C/N ratios in Pacific deep sea sediments: Effect of inorganic ammonium and organic nitrogen compounds sorbed by clays, Geochim. Cosmochim. Ac., 11, 765-776, 1977.

Müller, P. J., Suess, E., and Ungerer, C. A.: Amino acids and amino sugars of surface particulate and sediment trap material from waters of the Scotia Sea Deep-Sea Res. Pt. A, 33, 819-838, https://doi.org/10.1016/0198-0149(86)90090-7, 1986.

Nagel, B., Gaye, B., Kodina, L. A., and Lahajnar, N.: Stable carbon and nitrogen isotopes as indicators for organic matter sources in the Kara Sea, Mar. Geol., 266, 42-51, https://doi.org/10.1016/j.margeo.2009.07.010, 2009.

Nagel, B., Emeis, K.-C., Flohr, A., Rixen, T., Schlarbaum, T., Mohrholz, V., and van der Plas, A.: N-cycling and balancing of the $\mathrm{N}$-deficit generated in the oxygen minimum zone over the Namibian shelf - An isotope-based approach, J. Geophys. Res.Biogeo., 118, 361-371, 2013.

Nagel, B., Gaye, B., Lahajnar, N., Struck, U., and Emeis, K.C.: Effects of current regimes and oxygenation on particulate matter preservation on the Namibian shelf: Insights from amino acid biogeochemistry, Mar. Chem., 186, 121-132, https://doi.org/10.1016/j.marchem.2016.09.001, 2016.

Niggemann, J. and Schubert, C. J.: Sources and fate of amino sugars in coastal Peruvian sediments, Geochim. Cosmochim. Ac., 70, 2229-2237, 2006.

Niggemann, J., Lomstein, B. A., and Schubert, C. J.: Diagenesis of amino compounds in water column and sediment of Lake Baikal, Org. Geochem., 115, 67-77, https://doi.org/10.1016/j.orggeochem.2017.10.008, 2018.

Orellana, M. V. and Leck, C.: Marine Microgels, Biogeochemistry of Marine Dissolved Organic Matter, 2nd Edn., Academic Press Ltd.-Elsevier Science Ltd., London, 451-480, https://doi.org/10.1016/b978-0-12-405940-5.00009-1, 2015.

Pantoja, S., Sepúlveda, J., and Gonzálvez, H. E.: Decomposition of sinking proteinaceous material during fall in the oxygen minimum zone off northern Chile, Deep-Sea Res. Pt. I, 51, 55-70, 2004.

Parsek, M. R., Val, D. L., Hanzelka, B. L., Cronan Jr., J. E., and Greenberg, E. P.: Acyl homoserine-lactone quorum-sensing signal generation, P. Natl. Acad. Sci. USA, 96, 4360-4365, 1999.

Paul, S. A. L., Koschinsky, A., Gaye, B., and Dähnke, K.: Nisotopes and amino acids from sediment multi cores of SONNE cruise SO242/1 at the DISCOL area, Peru Basin, PANGAEA [data set], https://doi.org/10.1594/PANGAEA.881804, 2017a.

Paul, S. A. L., Koschinsky, A., Gaye, B., and Dähnke, K.: Nisotopes and amino acids from sediment push cores of SONNE cruise SO242/2 at the DISCOL area, Peru Basin, PANGAEA [data set], https://doi.org/10.1594/PANGAEA.881813, 2017b. 
Paul, S. A. L., Koschinsky, A., Gaye, B., and Dähnke, K.: Nisotopes and amino acids from CTD station SO242/1_58-1_CTD 4 at the DISCOL area, Peru Basin, PANGAEA [data set], https://doi.org/10.1594/PANGAEA.885391, 2017c.

Paul, S. A. L., Gaye, B., Haeckel, M., Kasten, S., and Koschinsky, A.: Biogeochemical Regeneration of a Nodule Mining Disturbance Site: Trace Metals, DOC and Amino Acids in DeepSea Sediments and Pore Waters, Front. Mar. Sci., 5, 117, https://doi.org/10.3389/fmars.2018.00117, 2018.

Peter, S., Shen Y., Kaiser, K., Benner, R., and Durisch-Kaiser, E.: Bioavailability and diagenetic state of dissolved organic matter in riparian groundwater, J. Geophys. Res. Geophys.l Res.h, 117, G04006, https://doi.org/10.1029/2012JG002072, 2012.

Peters, B. D., Lam, P. J., and Casciotti, K. L.: Nitrogen and oxygen isotope measurements of nitrate along the US GEOTRACES Eastern Pacific Zonal Transect (GP16) yield insights into nitrate supply, remineralization, and water mass transport, Mar. Chem., 201, 137-150, https://doi.org/10.1016/j.marchem.2017.09.009, 2018

Pilskaln, C. H. and Honjo, S.: The fecal pellet fraction of biogeochemical particle fluxes to the deep sea, Global Biogeochem. Сy., 1, 31-48, 1987.

Reinthaler, T., van Aken, H., Veth, C., Aristegui, J., Robinson, C., Williams, P., Lebaron, P., and Herndl, G. J.: Prokaryotic respiration and production in the meso- and bathypelagic realm of the eastern and western North Atlantic basin, Limnol. Oceanogr., 51, 1262-1273, https://doi.org/10.4319/lo.2006.51.3.1262, 2006.

Resplandy, L., Lévy, M., and McGillicuddy Jr., D. J.: Effects of Eddy-Driven Subduction on Ocean Biological Carbon Pump, Global Biogeochem. Cy., 33, 1071-1084, https://doi.org/10.1029/2018GB006125, 2019.

Riccardi, G., Derossi, E., and Milano, A.: Amino acid biosynthesis and its regulation in cyanobacteria, Plant Sci., 64, 135-151, https://doi.org/10.1016/0168-9452(89)90018-6, 1989.

Ridgwell, A. and Arndt, S.: Why Dissolved Organics Matter: DOC in Ancient Oceans and Past Climate Change, Biogeochemistry of Marine Dissolved Organic Matter, 2nd Edn., Academic Press Ltd.-Elsevier Science Ltd., London, 1-20, https://doi.org/10.1016/b978-0-12-405940-5.00001-7, 2015.

Rixen, T., Guptha, M. V. S., and Ittekkot, V.: Sedimentation, in: Report of the Indian Ocean Synthesis Group on the Arabian Sea Process Study, edited by: Burkill, P. and Smith, S. L., JGOFS Report 35, JGOFS International Project Office, Bergen, 65-73, 2002

Rixen, T., Baum, A., Gaye, B., and Nagel, B.: Seasonal and interannual variations in the nitrogen cycle in the Arabian Sea, Biogeosciences, 11, 5733-5747, https://doi.org/10.5194/bg-115733-2014, 2014.

Rixen, T., Gaye, B., and Emeis, K.-C.: The monsoon, carbon fluxes, and the organic carbon pump in the northern Indian Ocean, Prog. Oceanogr., 175, 24-39, https://doi.org/10.1016/j.pocean.2019.03.001, 2019a.

Rixen, T., Gaye, B., Emeis, K. C., and Ramaswamy, V.: The ballast effect of lithogenic matter and its influences on the carbon fluxes in the Indian Ocean, Biogeosciences, 16, 485-503, https://doi.org/10.5194/bg-16-485-2019, 2019b.

Robinson, R. S., Kienast, M., Luiza Albuquerque, A., Altabet, M., Contreras, S., De Pol Holz, R., Dubois, N., Francois, R., Galbraith, E., Hsu, T.-C., Ivanochko, T., Jaccard,
S., Kao, S.-J., Kiefer, T., Kienast, S., Lehmann, M., Martinez, P., McCarthy, M., Möbius, J., Pedersen, T., Quan, T. M., Ryabenko, E., Schmittner, A., Schneider, R., SchneiderMor, A., Shigemitsu, M., Sinclair, D., Somes, C., Studer, A., Thunell, R., and Yang, J.-Y.: A review of nitrogen isotopic alteration in marine sediments, Paleoceanography, 27, PA4203, https://doi.org/10.1029/2012PA002321, 2012.

Rontani, J.-F., Zabeti, N., and Wakeham, S. G.: Degradation of particulate organic matter in the equatorial Pacific Ocean: Biotic or abiotic?, Limnol. Oceanogr., 56, 333-349, 2011.

Satterberg, J., Arnarson, T. S., Lessard, E. J., and Keil, R. G.: Sorption of organic matter from four phytoplankton species to montmorillonite, chlorite and kaolinite in seawater, Mar. Chem., 81, 11-18, https://doi.org/10.1016/s0304-4203(02)00136-6, 2003.

Sheridan, C. C., Lee, C., Wakeham, S. G., and Bishop, J. K. B.: Suspended particle organic composition and cycling in surface and midwaters of the equatorial Pacific Ocean, Deep-Sea Res. Pt. I, 49, 1983-2008, 2002.

Silver, M. W., Coale, S. L., Pilskaln, C. H., and Steinberg, D. R.: Giant aggregates: Importance as microbial centers and agents of material flux in the mesopelagic zone, Limnol. Oceanogr., 43, 498-507, 1998.

Smith, D. C., Simon, M., Alldredge, A. L., and Azam, F.: Intense hydrolytic enzyme activity on marine aggregates and implications for rapid particle dissolution, Nature, 359, 139-142, 1992.

Suess, E.: Particulate organic carbon flux in the oceans - surface productivity and oxygen utilization, Nature, 288, 260-263, 1980.

Sun, Y., Zulla, M., Joachimski, M., Bond, D., Wignall, P., Zhang, Z., and Zhang, M.: Ammonium ocean following the endPermian mass extinction, Earth Planet. Sc. Lett., 518, 211-222, https://doi.org/10.1016/j.epsl.2019.04.036, 2019.

Suthhof, A., Jennerjahn, T. C., Schäfer, P., and Ittekkot, V.: Nature of organic matter in surface sediments from the Pakistan continental margin and the deep Arabian Sea: amino acids, Deep-Sea Res. Pt. II, 47, 329-351, 2000.

Suthhof, A., Ittekkot, V., and Gaye-Haake, B.: Millennial-scale oscillation of denitrification intensity in the Arabian Sea during the late Quaternary and its potential influence on atmospheric $\mathrm{N}_{2} \mathrm{O}$ and global climate, Global Biogeochem. Cy., 15, 637-650, 2001

Taylor, G. T.: Microbial degradation of sorbed and dissolved protein in seawater, Limnol. Oceanogr., 40, 875-885, 1995.

Tesdal, J. E., Galbraith, E. D., and Kienast, M.: Nitrogen isotopes in bulk marine sediment: linking seafloor observations with subseafloor records, Biogeosciences, 10, 101-118, https://doi.org/10.5194/bg-10-101-2013, 2013.

Turnewitsch, R., Lahajnar, N., Haeckel, M., and Christiansen, B.: An abyssal hill fractionates organic and inorganic matter in deep-sea surface sediments, Geophys. Res. Lett., 42, 7663-7672, https://doi.org/10.1002/2015gl065658, 2015.

Turnewitsch, R., Dale, A., Lahajnar, N., Lampitt, R. S., and Sakamoto, K.: Can neap-spring tidal cycles modulate biogeochemical fluxes in the abyssal nearseafloor water column?, Prog. Oceanogr., 154, 1-24, https://doi.org/10.1016/j.pocean.2017.04.006, 2017.

Unger, D., Gaye-Haake, B., Gebhardt, A. C., and Ittekkot, V.: Biogeochemistry of suspended and sedimentary material from the $\mathrm{Ob}$ and Yenisei rivers and the adjacent Kara Sea: Amino acids and amino sugars, Cont. Shelf Res., 25, 437-460, 2005. 
Wakeham, S. G. and Canuel, E. A.: Organic geochemistry of particulate matter in the eastern tropical North Pacific; Implications for particle dynamics, J. Mar. Res., 46, 183-213, 1988.

Wakeham, S. G. and Lee, C.: Organic geochemistry of particulate matter in the ocean - the role of particles in oceanic sedimentary cycles, Org. Geochem., 14, 83-96, https://doi.org/10.1016/01466380(89)90022-3, 1989.

Wakeham, S. G. and Lee, C.: Production, Transport, and Alteration of Particulate Organic Matter in the Marine Water Column, in: Organic Geochemistry: Principles and Applications, edited by: Engel, M. H. and Macko, S. A., Springer US, Boston, MA, 145169, https://doi.org/10.1007/978-1-4615-2890-6_6, 1993.

Wakeham, S. G., Lee, C., Farrington, J. W., and Gagosian, R. B.: Biogechemistry of particulate organic matter in the oceans: results from sediment trap experiments, Deep-Sea Res., 31, 509528, 1984.

Walla, M. D., Lau, P. Y., Morgan, S. L., Fox, A., and Brown, A.: Capillary gas chromatography-mass spectrometry of carbohydrate components of legionellae and other bacteria, J. Chromatogr. A, 288, 399-413, https://doi.org/10.1016/S00219673(01)93716-1, 1984.

Waples, D. W. and Sloan, J. R.: Carbon and nitrogen diagenesis in deep-sea sediments, Geochim. Cosmochim. Ac., 44, 1463-1470, https://doi.org/10.1016/0016-7037(80)90111-8, 1980.

Whelan, J. K. and Emeis, K.-C.: Preservation of amino acids and carbohydrates in marine sediments, in: Organic Matter: Productivity, Accumulation, and Preservation in Recent and Ancient Sediments, edited by: Whelan, J. K. and Farrington, J., Columbia University Press, Palisades, N. Y., 176-200, ISBN 023107162 $0,1992$.
Wilson, J. D., Barker, S., and Ridgwell, A.: Assessment of the spatial variability in particulate organic matter and mineral sinking fluxes in the ocean interior: Implications for the ballast hypothesis, Global Biogeochem. Cy., 26, GB4011, https://doi.org/10.1029/2012gb004398, 2012.

Xue, J. H., Lee, C., Wakeham, S. G., and Armstrong, R. A.: Using principal components analysis (PCA) with cluster analysis to study the organic geochemistry of sinking particles in the ocean, Org. Geochem., 42, 356-367, https://doi.org/10.1016/j.orggeochem.2011.01.012, 2011.

Yamaguchi, Y. T. and McCarthy, M. D.: Sources and transformation of dissolved and particulate organic nitrogen in the North Pacific Subtropical Gyre indicated by compound-specific a ${ }^{15} \mathrm{~N}$ analysis of amino acids, Geochim. Cosmochim. Ac., 220, 329-347, https://doi.org/10.1016/j.gca.2017.07.036, 2018.

Yang, J.-Y. T., Kao, S.-J., Dai, M., Yan, X., and Lin, H.L.: Examining $\mathrm{N}$ cycling in the northern South China Sea from $\mathrm{N}$ isotopic signals in nitrate and particulate phases, J. Geophys. Res.-Biogeo., 122, 2118-2136, https://doi.org/10.1002/2016JG003618, 2017.

Zhang, P. Y., Yang, G. P., Chen, Y., Leng, W. S., and Ji, C. X.: Temporal and spatial variations of particulate and dissolved amino acids in the East China Sea, Mar. Chem., 186, 133-144, https://doi.org/10.1016/j.marchem.2016.09.004, 2016. 